Review

\title{
Establishment of Metabolism and Transport Pathways in the Rodent and Human Fetal Liver
}

\author{
Jamie E. Moscovitz ${ }^{1}$ and Lauren M. Aleksunes ${ }^{1,2, *}$
}

1 Department of Pharmacology and Toxicology, Rutgers University Ernest Mario School of Pharmacy, 170 Frelinghuysen Rd., Piscataway, NJ 08854, USA; E-Mail: jamie.moscovitz@rutgers.edu

2 Environmental and Occupational Health Sciences Institute, 170 Frelinghuysen Rd., Piscataway, NJ 08854, USA

* Author to whom correspondence should be addressed; E-Mail: aleksunes@eohsi.rutgers.edu; Tel.: +1-848-445-5518; Fax: +1-732-445-0119.

Received: 5 November 2013; in revised form: 25 November 2013 / Accepted: 26 November 2013 / Published: 6 December 2013

\begin{abstract}
The ultimate fate of drugs and chemicals in the body is largely regulated by hepatic uptake, metabolism, and excretion. The liver acquires the functional ability to metabolize and transport chemicals during the perinatal period of development. Research using livers from fetal and juvenile rodents and humans has begun to reveal the timing, key enzymes and transporters, and regulatory factors that are responsible for the establishment of hepatic phase I and II metabolism as well as transport. The majority of this research has been limited to relative mRNA and protein quantification. However, the recent utilization of novel technology, such as RNA-Sequencing, and the improved availability and refinement of functional activity assays, has begun to provide more definitive information regarding the extent of hepatic drug disposition in the developing fetus. The goals of this review are to provide an overview of the early regulation of the major phase I and II enzymes and transporters in rodent and human livers and to highlight potential mechanisms that control the ontogeny of chemical metabolism and excretion pathways.
\end{abstract}

Keywords: fetal; metabolism; transport; regulation; prenatal; phase I; phase II; Abc; Slc; ontogeny 
Abbreviations: Abc, ATP-binding cassette; Adh, alcohol dehydrogenase; Akr, aldo-keto reductase; Aldh, aldehyde dehydrogenase; Bcrp, breast cancer resistance protein; Bsep, bile salt export pump; Car, constitutive androstane receptor; Ces, carboxylesterase; Cyp, cytochrome P450; Ent, equilibrative nucleoside transporter; Fgf, fibroblast growth factor; Fmo, flavin-containing monooxygenase; Fxr, farnesoid X receptor; Gst, glutathione $S$-transferase; Hnf, hepatic nuclear factor; Lxr, liver X receptor; Mate, multidrug and toxin extrusion; Mdr, multidrug resistance; Mrp, multidrug resistance-associated protein; Nat, $N$-acetyl transferase; Ntcp, sodium taurocholate co-transporting polypeptide; Oat, organic anion transporter; Oatp, organic anion transporting polypeptide; Oct, organic cation transporter; Ost, organic solute transporter; Ppar, peroxisome proliferator-activated receptor; Pxr, pregnane X receptor; Slc, solute carrier; Sult, sulfotransferase; Ugt, UDP-glucuronosyl transferase.

\section{Introduction}

Xenobiotics that enter the body commonly undergo metabolism by phase I and/or phase II enzymes in the liver. Hepatic phase I reactions can include oxidation, reduction, or hydrolysis, and are predominantly performed by cytochrome P450 (Cyp), flavin-containing monooxygenase (Fmo), and carboxylesterase (Ces) enzymes. Phase II reactions include the addition of an endogenous compound to a xenobiotic by a transferase such as glutathione $S$-transferase (Gst), sulfotransferase (Sult), UDP-glucuronosyl transferase (Ugt), and $N$-acetyl transferase (Nat). In order for large and/or charged molecules to gain access to metabolizing enzymes, transporters may be required to bring chemicals from sinusoidal blood into hepatocytes. In addition, transporters mediate the removal of chemicals from cells, in particular, conjugated xenobiotics following phase II metabolism. Two important superfamilies of transporters include the solute carrier (Slc) and ATP-binding cassette (Abc) transporters, which are generally involved in the uptake and efflux of substances, respectively. Similar to metabolic enzymes, each transporter isoform can have unique specificity and affinity for substrates. Together, metabolizing enzymes and transporters account for a large proportion of the biotransformation and disposition of chemicals in the body.

The fields of pharmacology, toxicology, and medicine have benefited greatly from advancements in understanding the developmental profiles of hepatic phase I and II drug metabolism and transport. These data have aided in chemical risk assessment, exposure modeling, and age-appropriate pharmacotherapy. In toxicology, the knowledge of the developmental profiles for disposition pathways has helped to identify human populations that are susceptible, as well as resistant, to the effects of different environmental chemicals and drugs. Still, more research is needed to understand the ontogeny and underlying regulation of these processes.

The fetal period of development is characterized by tissue differentiation and growth, and is designated as gestation day 17 to birth (days 19-22) in mice and rats, and day 56 to birth (day 267) in humans. Between gestation days 9.5 and 15 in mice, as well as days 60 and 195 in humans, the liver is the predominant hematopoietic site in the body. Following this period, primary erythropoiesis shifts to the bone marrow, while hematopoiesis gradually decreases in the liver. Around gestation day 13, hepatoblasts mature into functional rodent hepatocytes and begin the early formation of a biliary network, which continues through birth. 
It was first observed in the 1950s that the drug metabolizing capabilities of the newborn rabbit liver are not mature at birth because of a differing enzyme profile [1]. Subsequently, we have learned that drug metabolizing enzyme and transporter expression in the fetal and neonatal periods follow several developmental patterns, and vary for each subfamily and isoform. Resources to understand the functioning of the human fetal liver are limited, and thus rodent models have been primarily used to study this important stage of development. In recent years, however, the availability of human fetal tissues has increased, providing greater insight into the ontogeny of drug metabolism and transport across species.

This review article provides a broad overview of the rodent and human studies that characterize the regulation of phase I and II enzymes and transporters during fetal liver development. Lowercase letter abbreviations have been used to denote rodent gene and protein isoforms and uppercase letter abbreviations refer to human orthologs. While the majority of studies have focused on mRNA regulation, there are some data regarding functional changes during hepatic development that will be discussed. In this review, attention will be placed upon regulatory pathways, including transcriptional and epigenetic factors, that contribute to the programming of biotransformation and excretion.

\section{Phase I Metabolism}

While phase I drug metabolism in the fetal liver is relatively immature compared to the adult liver, it does exist primarily as a result of Cyp enzyme activity. Although other phase I enzymes may be present before birth, their expression is quite low. The mRNA and/or protein expression of rodent and human aldehyde dehydrogenase (Aldh) [2,3] and Fmo isoforms [3-6] in fetal livers is much less than observed in adults (Table 1). Likewise, the expression and/or activity of Ces enzymes is rather diminished $[3,7,8]$. While there are exceptions, such as human FMO1, which has been detected in second trimester fetal livers $[5,6]$, the majority of phase I metabolism during early development appears to be Cyp-mediated biotransformation and thus, most research in this field has focused on Cyp enzymes.

Table 1. Phase I metabolism (non-cytochrome P450) in rodent and human fetal livers. ${ }^{1}$

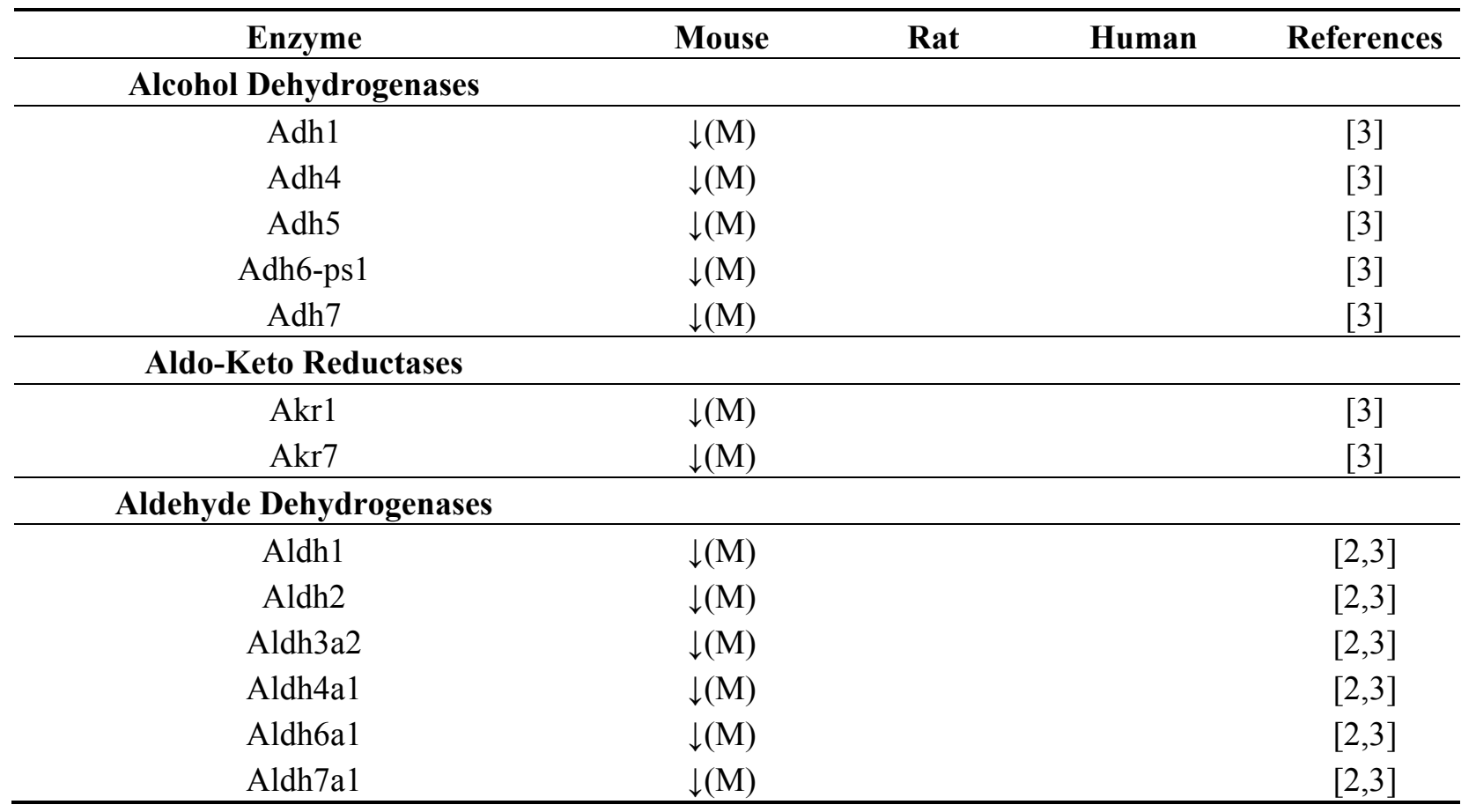


Table 1. Cont.

\begin{tabular}{ccccc}
\hline Enzyme & Mouse & Rat & Human & References \\
\hline Carboxylesterases & & & & \\
\hline Ces & & $\downarrow(\mathrm{A})$ & & {$[7]$} \\
Ces1/CES1 & $\downarrow(\mathrm{M})$ & & $\downarrow(\mathrm{M}, \mathrm{P}, \mathrm{A})$ & {$[3,8]$} \\
Ces2/CES2 & $\downarrow(\mathrm{M})$ & & $\downarrow(\mathrm{M})$ & {$[3,8]$} \\
Ces3 & $\downarrow(\mathrm{M})$ & & & {$[3]$} \\
\hline Flavin-Containing Monooxygenases & & & \\
\hline Fmo1/FMO1 & $\downarrow(\mathrm{M}) \leftrightarrow(\mathrm{P})$ & & & \\
Fmo2 & $\downarrow(\mathrm{M})$ & & & {$[3-6]$} \\
Fmo3/FMO3 & $\downarrow(\mathrm{M}, \mathrm{P})$ & & $\leftrightarrow(\mathrm{M})$ & {$[3-5]$} \\
Fmo4/FMO4 & $\leftrightarrow(\mathrm{M})$ & & & {$[3,5]$} \\
Fmo5 & $\downarrow(\mathrm{M}, \mathrm{P})$ & & {$[3,4]$} \\
\hline
\end{tabular}

${ }^{1}$ Expression or activity compared to adult liver levels. mRNA expression (M), protein expression (P), and activity (A) are noted; $\uparrow$ denotes up-regulation; $\downarrow$ denotes down-regulation; and $\leftrightarrow$ denotes no change. Human orthologs are indicated only for isoforms with human data.

\subsection{Cytochrome P450 Enzymes}

CYP enzymes oxidize a variety of exogenous and endogenous substrates. They are highly expressed in the liver, as well as the lungs and kidneys. The mouse liver expresses 31 of the 102 total Cyp enzymes that have been identified [9,10]. This is the largest number of Cyp isoforms present in a single mouse tissue. In contrast, 57 CYP enzymes have been identified in humans [10]. While not all mouse Cyp isoforms have been shown to metabolize specific substrates, more than half exhibit sequence homology to human isoforms $[10,11]$. The fetal liver mRNA, protein and/or activity of Cyp/CYP enzymes in rodents and humans has been characterized relative to adult levels and summarized in Table 2.

Table 2. Phase I metabolism (cytochrome P450) in rodent and human fetal livers.

\begin{tabular}{ccccc}
\hline Enzyme & Mouse & Rat & Human & References \\
\hline Cytochrome P450s & & & & \\
\hline Cyp1a1/CYP1A1 & & $\uparrow(\mathrm{M}) \downarrow(\mathrm{A})$ & $\downarrow(\mathrm{M}, \mathrm{P}, \mathrm{A})$ & {$[7,12,13]$} \\
Cyp1a2/CYP1A2 & $\downarrow(\mathrm{M})$ & $\downarrow(\mathrm{M}, \mathrm{A})$ & $\downarrow(\mathrm{M}, \mathrm{P}, \mathrm{A})$ & {$[7,11-15]$} \\
Cyp1b1/CYP1B1 & $\downarrow(\mathrm{M})$ & & $\uparrow(\mathrm{M})$ & {$[11,13]$} \\
Cyp2a4 & $\downarrow(\mathrm{M})$ & & & {$[11,14,15]$} \\
Cyp2a5 & $\downarrow(\mathrm{M})$ & & & {$[14,15]$} \\
Cyp2a12 & $\downarrow(\mathrm{M})$ & & & {$[14,15]$} \\
Cyp2a22 & $\downarrow(\mathrm{M})$ & & {$[14]$} \\
Cyp2b1 & & $\downarrow(\mathrm{M}, \mathrm{A})$ & & {$[7,16,17]$} \\
Cyp2b2 & & $\downarrow(\mathrm{M}, \mathrm{A})$ & & {$[14,15]$} \\
Cyp2b9 & $\downarrow(\mathrm{M})$ & & {$[1,14,15]$} \\
Cyp2b10 & $\downarrow(\mathrm{M})$ & & {$[14]$} \\
Cyp2b13 & $\downarrow(\mathrm{M})$ & & & {$[16]$} \\
Cyp2b23 & $\downarrow(\mathrm{M})$ & & & \\
Cyp2c6 & & $\downarrow(\mathrm{M})$ & \\
\hline
\end{tabular}


Table 2. Cont.

\begin{tabular}{|c|c|c|c|c|}
\hline Enzyme & Mouse & Rat & Human & References \\
\hline Cyp2c7 & & $\downarrow(\mathrm{M})$ & & {$[17]$} \\
\hline CYP2C9 & & & $\downarrow(\mathrm{P}, \mathrm{A})$ & {$[18]$} \\
\hline CYP2C19 & & & $\downarrow(\mathrm{P}, \mathrm{A})$ & {$[18]$} \\
\hline Cyp2c29 & $\downarrow(\mathrm{M})$ & & & {$[14,15]$} \\
\hline Сyp2c37 & $\downarrow(\mathrm{M})$ & & & {$[14]$} \\
\hline Cyp2c38 & $\downarrow \leftrightarrow(\mathrm{M})$ & & & {$[14,15]$} \\
\hline Сyp2c39 & $\downarrow \leftrightarrow(\mathrm{M})$ & & & {$[14,15]$} \\
\hline Сyp2c40 & $\downarrow(\mathrm{M})$ & & & {$[14]$} \\
\hline Cyp2c44 & $\downarrow(\mathrm{M})$ & & & {$[14,15]$} \\
\hline Сyp2c50 & $\downarrow(\mathrm{M})$ & & & {$[14,15]$} \\
\hline Сyp2c54 & $\downarrow(\mathrm{M})$ & & & {$[14,15]$} \\
\hline Сyp2c55 & $\downarrow(\mathrm{M})$ & & & {$[14]$} \\
\hline Сyp2c66 & $\downarrow(\mathrm{M})$ & & & {$[11]$} \\
\hline Сур2c67 & $\downarrow(\mathrm{M})$ & & & {$[14]$} \\
\hline Cyp2c68 & $\downarrow(\mathrm{M})$ & & & {$[14,15]$} \\
\hline Сур2c69 & $\downarrow(\mathrm{M})$ & & & {$[14]$} \\
\hline Сyp2c70 & $\downarrow(\mathrm{M})$ & & & {$[14,15]$} \\
\hline Сyp2d9 & $\downarrow(\mathrm{M})$ & & & {$[14,15]$} \\
\hline Cyp2d10 & $\downarrow(\mathrm{M})$ & & & {$[14,15]$} \\
\hline Cyp2d11 & $\downarrow(\mathrm{M})$ & & & {$[14]$} \\
\hline Cyp2d12 & $\downarrow(\mathrm{M})$ & & & {$[14]$} \\
\hline Сур2d13 & $\downarrow \leftrightarrow(\mathrm{M})$ & & & {$[14,15]$} \\
\hline Cyp2d22 & $\downarrow(\mathrm{M})$ & & & {$[11,14,15]$} \\
\hline Cyp2d26 & $\downarrow(\mathrm{M})$ & & & {$[14,15]$} \\
\hline Cyp2d34 & $\downarrow(\mathrm{M})$ & & & {$[14]$} \\
\hline Cyp2d37-ps & $\downarrow(\mathrm{M})$ & & & {$[14]$} \\
\hline Сур2d40 & $\downarrow(\mathrm{M})$ & & & [14] \\
\hline Сyp2e1/CYP2E1 & $\downarrow(\mathrm{M})$ & $\downarrow(\mathrm{M}, \mathrm{A})$ & $\downarrow(\mathrm{M})$ & {$[7,11,13-15]$} \\
\hline Сур2f2 & $\downarrow(\mathrm{M})$ & & & {$[11,14,15]$} \\
\hline Cyp2g1 & $\downarrow \leftrightarrow(\mathrm{M})$ & & & {$[14,15]$} \\
\hline Сyp2j5 & $\downarrow(\mathrm{M})$ & & & {$[14,15]$} \\
\hline Сур2j6 & $\downarrow(\mathrm{M})$ & & & {$[11,14]$} \\
\hline Cyp2r1/CYP2R1 & $\downarrow(\mathrm{M})$ & & $\downarrow(\mathrm{M})$ & {$[13,14]$} \\
\hline Cyp2s1/CYP2S1 & & & $\downarrow(\mathrm{M})$ & {$[13]$} \\
\hline Сур2u1/CYP2U1 & $\downarrow(\mathrm{M})$ & & $\downarrow(\mathrm{M})$ & {$[13,14]$} \\
\hline Сур2w1/CYP2W1 & & & $\uparrow(\mathrm{M})$ & [13] \\
\hline Cyp3a1 & & $\downarrow(\mathrm{M}, \mathrm{A})$ & & {$[7,16,17]$} \\
\hline Сур3a2 & & $\downarrow\left(\partial^{\lambda} \mathrm{M}, \mathrm{A}\right) \uparrow(\uparrow \mathrm{M})$ & & [7] \\
\hline Сур3a11/CYP3A4 & $\downarrow(\mathrm{M})$ & $\downarrow(\mathrm{M})$ & $\downarrow(\mathrm{M}, \mathrm{P}, \mathrm{A})$ & {$[11,14,15,19-24]$} \\
\hline CYP3A5 & & & $\leftrightarrow(\mathrm{M}, \mathrm{P}, \mathrm{A})$ & {$[19,21]$} \\
\hline Сур3a13 & $\downarrow(\mathrm{M})$ & & & {$[11,14,15]$} \\
\hline Сур3a16/СYР3А7 & $\uparrow \leftrightarrow(\mathrm{M})$ & & $\uparrow(\mathrm{M}, \mathrm{P}, \mathrm{A})$ & {$[11,14,15,19-21]$} \\
\hline Сур3а25 & $\downarrow(\mathrm{M})$ & & & {$[11,14,15]$} \\
\hline Сур3a41a/b & $\uparrow\left(\jmath^{\lambda}\right) \downarrow(\uparrow \mathrm{M})$ & & & {$[11,14,15]$} \\
\hline Сур3а44 & $\downarrow(\mathrm{M})$ & & & {$[14,15]$} \\
\hline
\end{tabular}


Table 2. Cont.

\begin{tabular}{|c|c|c|c|c|}
\hline Enzyme & Mouse & Rat & Human & References \\
\hline Cyp3a59 & $\downarrow(\mathrm{M})$ & & & [14] \\
\hline Cyp4a1 & & $\leftrightarrow(\mathrm{M}) \downarrow\left(\jmath^{\lambda}\right) \uparrow(q \mathrm{~A})$ & & {$[7]$} \\
\hline Сур4a10 & $\downarrow(\mathrm{M})$ & & & {$[11,14,15]$} \\
\hline Cyp4a12a/b & $\downarrow(\mathrm{M})$ & & & [14] \\
\hline Cyp4a14 & $\downarrow \leftrightarrow(\mathrm{M})$ & & & {$[14,15]$} \\
\hline Сур4а31 & $\downarrow(\mathrm{M})$ & & & {$[14,15]$} \\
\hline Сур4а32 & $\downarrow(\mathrm{M})$ & & & {$[14]$} \\
\hline Сур4b1/CYP4B1 & $\downarrow(\mathrm{M})$ & & $\downarrow(\mathrm{M})$ & {$[13,14]$} \\
\hline Cyp4f13 & $\downarrow \leftrightarrow(\mathrm{M})$ & & & {$[14,15]$} \\
\hline Cyp4f14 & $\downarrow(\mathrm{M})$ & & & {$[14,15]$} \\
\hline Cyp4f15 & $\downarrow(\mathrm{M})$ & & & {$[14,15]$} \\
\hline Сур4f16 & $\downarrow(\mathrm{M})$ & & & {$[14]$} \\
\hline Сур4f1 8 & $\downarrow \leftrightarrow(\mathrm{M})$ & & & {$[11,14]$} \\
\hline Сур4f39 & $\downarrow(\mathrm{M})$ & & & {$[14]$} \\
\hline Cyp4v3 & $\downarrow(\mathrm{M})$ & & & {$[14,15]$} \\
\hline Сур4x1/CYP4X1 & $\downarrow(\mathrm{M})$ & & $\downarrow(\mathrm{M})$ & {$[13]$} \\
\hline Cyp7a1 & $\downarrow \leftrightarrow(\mathrm{M})$ & $\downarrow(\mathrm{M})$ & & {$[14,15,22,23]$} \\
\hline Сур7b1 & $\downarrow \leftrightarrow(\mathrm{M})$ & & & {$[14,15,22]$} \\
\hline Cyp8b1 & $\downarrow(\mathrm{M})$ & $\downarrow(\mathrm{M})$ & & {$[14,15,22,23]$} \\
\hline Сур17a1 & $\downarrow(\mathrm{M})$ & & & [14] \\
\hline Сур20a1 & $\downarrow(\mathrm{M})$ & & & {$[14]$} \\
\hline Сур26a1 & $\downarrow(\mathrm{M})$ & & & {$[14,15]$} \\
\hline Cyp26b1 & $\downarrow(\mathrm{M})$ & & & {$[14]$} \\
\hline Сур27 & & $\downarrow(\mathrm{M})$ & & {$[23]$} \\
\hline Сур27a1 & $\downarrow(\mathrm{M})$ & & & {$[14,15,22]$} \\
\hline Cyp39a1 & $\downarrow(\mathrm{M})$ & & & [14] \\
\hline Cyp51 & $\downarrow \leftrightarrow(\mathrm{M})$ & & & {$[14,15]$} \\
\hline
\end{tabular}

${ }^{1}$ Expression or activity compared to adult liver levels. mRNA expression (M), protein expression (P), and activity (A) are noted; $\uparrow$ denotes up-regulation; $\downarrow$ denotes down-regulation; and $\leftrightarrow$ denotes no change. Specific data for females $(+)$ or males $\left({ }^{\lambda}\right)$ are noted. Human orthologs are indicated only for isoforms with human data. No data is available for Cyp3a57, Cyp4f17, and Cyp4f40.

\subsubsection{Mouse Cyp Regulation}

In general, gene expression of most Cyps is low in the mouse fetal liver, and gradually increases with advancing age. mRNA and protein for many Cyp isoforms can be subsequently detected at postnatal days 15 to 20 and beyond, when their expression is equivalent to that of an adult mouse liver [2,11]. Notably, Cyp3a16 and 3a41b transcripts are enriched perinatally (two days before birth through 5 days after birth), while adult mRNA levels of these isoforms are detectable but low $[11,14]$. While these two isoforms are preferentially higher during this developmental window, the absolute abundance of their mRNAs is lower than other Cyp isoforms found in the fetal liver (such as Cyp2d26). 


\subsubsection{Rat Cyp Regulation}

Several isoforms that exhibit elevated mRNA expression and/or activity in the rat fetal period, such as Cyp1a1, 3a2 and 4a1, have been identified [7]. Despite the fact that mRNA levels of Cypla1 have been shown to be 1.5-fold higher in the fetal liver than the adult liver, no activity for Cyp1a1 in fetal tissues has been measurable (assessed by oxidative deethylation of 7-ethoxyresorufin) [7]. Interestingly, up-regulation of fetal hepatic mRNA for Cyp1a1, as well as Cyp1a2, 2b1, and 3a2 is seen with exposure of pregnant rats to the environmental contaminant, polybrominated diphenyl ether, BDE-99 [25]. In this study, elevated Cyp mRNA following BDE-99 treatment coincided with generation of lipid peroxides and increased activity of catalase. These data suggest that while Cyps are modestly expressed in the rat fetal liver, they may be inducible by xenobiotics, which could impact hormone signaling and endocrine programming during development.

Sex-specific differences in the fetal establishment of Cyp3a2 and 4a1 mRNA expression and activity have been demonstrated. Cyp3a 2 is a male-specific Cyp isoform that metabolizes a variety of drugs and steroids, while Cyp4a1 participates in hepatic lipid metabolism. Compared to levels found in adult rat livers, Cyp3a2 mRNA is higher in female fetuses, and lower in male fetuses. It should be noted that the activity for Cyp3a2 is negligible in both sexes, as quantified by $N$-ethylmorphine $\mathrm{N}$-demethylation. Fetal Cyp4a1 mRNA transcripts are equivalent to that of the adult liver, whereas activity measured by lauric acid $\omega$-hydroxylation is increased by $190 \%$ in female rat fetuses and decreased by $70 \%$ in male rat fetuses relative to the adult activity of the respective sex [7]. Additional studies are needed to better understand the gender divergent regulation of fetal Cyp enzymes and the importance of these differences for lipid and steroid metabolism.

\subsubsection{Human CYP Regulation}

Total CYP enzyme protein in the human fetal liver has been reported as $30 \%$ to $60 \%$ of adults [26-28]. Of these CYPs, the human CYP3A subfamily is critical for xenobiotic metabolism, and is likely the best characterized class of Phase I enzymes. CYP3A7 accounts for 30\% of total fetal CYP content, and exhibits its highest expression on postnatal days 1 to 7 [19]. Fetal CYP3A7 mRNA and protein expression, as well as catalytic activity, have been demonstrated by several studies and discussed in a prior review [20,21,29]. Following this early postnatal period, there is a change from CYP3A7-predominant to CYP3A4-predominant activity in the liver. This is illustrated by a higher propensity for 16-alpha hydroxylation of dehydroepiandrosterone by CYP3A7 during gestation and a transition to testosterone 6-beta hydroxylase activity associated with CYP3A4 after birth [20]. Prior to this shift away from CYP3A7-mediated metabolism, the fetus has $10 \%$ of the adult content of CYP3A4 [19]. The related CYP isoform, CYP3A5, exhibits high inter-individual differences in protein, with no change between the fetal, perinatal, and postnatal periods [19,21]. Other prominent human CYP isoforms, such as CYP2D6 and CYP2E1, have low fetal protein ( $10 \%$ of adult values) [29-31], and do not typically increase until adolescence. Both CYP2D6 and CYP2E1 also exhibit high inter-individual differences, similar to CYP3A5. While CYP2C19 protein and activity is consistently low throughout the fetal period (10\%-15\% adult levels), CYP2C 9 protein and activity is $1 \%$ of adult levels in the first trimester, increasing to $30 \%$ during the second and third trimesters [18,29]. CYP1A2 
is the final major drug metabolizing isoform to develop in the human liver [12]. CYP1A2 protein is undetectable in the fetal liver and increases modestly to $50 \%$ of adult levels around one year of age [12].

Although many orthologs exhibit similar fetal enzymatic profiles in both rodent and human livers, there are some exceptions. Whereas CYP3A7 "switches" with CYP3A4 by 1 to 2 years of age in humans, the mouse ortholog Cyp3a16 is relatively stable and has sustained expression through adolescence when there is a developmental shift to Cyp3a11, the adult isoform [19-21,32,33]. Additional research is needed to better understand the mechanism(s) underlying the differences in CYP3A/Cyp3a ontogeny between species.

\subsubsection{Bile Acid-Related Cyps}

Bile acid enzyme mRNAs of the classic synthetic pathway, Cyp7a1 and Cyp8b1, are low two days before birth in mice, and increase by approximately 14- and 8-fold at parturition, respectively [22]. This up-regulation at birth correlates with a surge in the major bile acid of the classic pathway, cholic acid, as well as its conjugates. It is hypothesized that the up-regulation of bile acid synthesis enzymes is due, in part, to activation of the liver X receptor (Lxr), as well as suppression of fibroblast growth factor 15 (Fgf15), which together promote transcription of Cyp7a1 [22]. Conversely, enzymes of the alternative synthesis pathway, namely Cyp27a1 and Cyp7b1, are less than 3\% of adult levels two days before birth, and stay low until days 20 to 30, and are likely under different regulatory control mechanisms [22].

\subsection{Carboxylesterase Enzymes}

CES enzymes hydrolyze chemicals with ester, thioester, or amide bonds. They can be localized to the endoplasmic reticulum as well as the cytosol. CES enzymes are highly expressed in the liver, small intestine, kidneys, and lungs. Mouse Ces 1 mRNA comprises 58\% of total adult liver Ces transcripts, while Ces 2 and Ces3 families are also present [3]. Isoforms of all three families are low in the fetal liver as compared to the adult, with gradual increases in enrichment from birth to day 45 [3]. In addition, rat fetal hepatic microsomes exhibit $\sim 15 \%$ of the hydrolysis of the model Ces substrate $p$-nitrophenyl acetate, as compared to microsomes generated from adult animals [7]. Considerable work has documented the increasing expression and activity of CESs with age, across multiple species including mouse, rat, and human. These studies have focused on the role of CES in the detoxification of different insecticides and pesticides, including pyrethroids such as deltamethrin and organophosphates such as parathion [8,34-37]. Because of the delayed establishment of CES-mediated metabolism, juvenile mammals can have increased systemic exposure to environmental chemicals and drugs that may lead to significant toxicity.

\subsection{Absolute Expression of Phase I Enzymes in Fetal and Neonatal Mouse Liver}

In recent years, researchers have begun to apply novel technologies to understand the developmental regulation of drug metabolism pathways in mice. This includes the use of RNA-Sequencing, which is a next generation sequencing technology that simultaneously quantifies RNA transcripts and variants. Using RNA-Sequencing, two recent studies have comprehensively quantified the expression of phase I 
enzymes in the fetal mouse liver (two days prior to birth) $[3,14]$. The most abundant transcripts include Cyps (35\%), followed by Aldhs (25\%), Aldo-keto reductases (Akrs, 21\%), and Alcohol dehydrogenases (Adhs, 10\%) [3]. Cyp2d26 accounts for $40 \%$ of the total Cyp mRNAs two days prior to birth, followed by Cyp2c68 (8\%), and Cyp2d10 (7\%), with all other isoforms at less than 6\% [14]. In addition to these Cyp enzymes, a number of other phase I enzymes are enriched including Akr1a4, Adh5, Aldh2, and Aldh4a1 [3,14].

Recently, analysis of 12 human fetal livers has identified low (ADH7, ALDH3B2, ALD1A3, CES5A, CES3, CYP4F8, CYP26C1, CYP11B2, FMO2) and high (ADH1A, ADH6, ADH5, ALDH1A1, ALDH2, ALDH4A1, CYP3A7, CYP27A1, CYP19A1, FMO5) expression of phase I metabolizing enzymes using RNA-Sequencing [38].

\subsection{Potential Mechanisms for the Regulation of Phase I Metabolism during Ontogeny}

Several hypotheses have been presented to explain the expression patterns for drug metabolizing enzymes during different developmental windows. It has been suggested that the greatest contributor to expression patterns during these periods is the changing environment. This hypothesis is supported by changes in both rodent and human phase I enzymatic profiles regardless of the exact gestational day at birth [19,20,32]. In addition, some phase I enzymes may serve developmental functions, as opposed to xenobiotic metabolic activity, which could account for their early, albeit low expression $[9,11,13,29,32]$. For example, critical developmental function has been documented for Cyp1b1/CYP1B1 which is associated with proper eye formation and Cyps that participate in bile acid synthesis [9,22,39]. Similarly, there is a higher extrahepatic mRNA expression of mouse fetal Aldh enzymes critical for the synthesis of retinoic acid, though still at lower levels than adults [2]. While a number of phase I enzymes have been shown to support organogenesis and organ function in other tissues during development, there is the potential for additional isoforms to contribute to the establishment of key hepatic functions.

Gene clusters and transcription factors are also proposed as mediators that control the fetal and neonatal expression of CYPs. In some instances, genes encoding related CYP isoforms cluster on the same region of a chromosome and as a consequence share similar ontogenic expression patterns [32]. Studies have also shown that limited Cyp gene expression during fetal development coincides with low levels of upstream transcription factors, namely the nuclear receptors constitutive androstane receptor (Car), farnesoid $\mathrm{X}$ receptor (Fxr), pregnane $\mathrm{X}$ receptor (Pxr), and peroxisome proliferator-activated receptor alpha (Ppar $\alpha)[22,32,40]$. Supporting the hypothesis that reduced nuclear receptors lead to minimal Cyp expression in the fetus, there are parallel increases in both gene families after birth. For example, it was shown that binding of mouse hepatic nuclear factor (Hnf) 4 alpha to the promoter region of Pxr can activate nuclear receptor signaling in primary fetal hepatocytes [41]. Likewise, the absence of Hnf4 $\alpha$ in these cells can cause the down-regulation of both Pxr and target gene Cyp3a11 [41]. While this is an interesting example, additional studies are necessary to clarify transcription factor-related mechanisms of fetal hepatic phase I enzyme down-regulation.

More recent attention has also been placed on the epigenetic regulation of drug metabolizing enzymes (reviewed in [42]). Postnatal changes in histone modifications have been associated with the transition in expression from the fetal Cyp3a16 isoform to the adult Cyp3a11 isoform during development [33]. Specifically, histone methylation patterns in the promoter region of hepatic Cyp3a16 
in adult mice are indicative of gene silencing. Likewise, in mice, the Cyp1a2 promoter is hypermethylated at birth when hepatic gene expression is low. Following birth, the $\mathrm{CpG}$ islands in the promoter become demethylated and mRNA levels of Cypla2 increase [43]. These studies suggest a role for both DNA methylation and histone modifications in the ontogenic regulation of Cyp enzymes.

\section{Phase II Metabolism}

Similar to phase I enzymes, most phase II enzymes are not significantly expressed until the neonatal period, with some important exceptions (Table 3). Of the phase II genes that are expressed in the liver during this time frame, hierarchical clustering suggests that their biological functions are most related to peptide metabolism, glutathione synthesis and turnover, generation of $S$-adenosylmethionine and bile acid homeostasis [44]. Many early studies investigated the presence or absence of entire phase II enzyme families in the fetus, however this review will focus on specific phase II enzyme subfamilies and isoforms that have been identified in the fetal liver.

Table 3. Phase II metabolism in rodent and human fetal livers. ${ }^{1}$

\begin{tabular}{|c|c|c|c|c|}
\hline Enzyme & Mouse & Rat & Human & References \\
\hline \multicolumn{5}{|l|}{ Sulfotransferases } \\
\hline Sult1a1/SULT1A1 & $\downarrow \leftrightarrow(\mathrm{M})$ & & $\leftrightarrow \downarrow(\mathrm{P}) \downarrow(\mathrm{A})$ & {$[15,44-49]$} \\
\hline SULT1A3 & & & $\uparrow(\mathrm{P}, \mathrm{A})$ & {$[46,47,49,50]$} \\
\hline Sult1b1 & $\downarrow\left(\circlearrowright^{\lambda} \mathrm{M}\right)$ & & & {$[44]$} \\
\hline Sult1c1/SULT1C1 & $\uparrow(\mathrm{M})$ & & & [45] \\
\hline Sult1c2/SULT1C2 & $\downarrow(\mathrm{M})$ & & $\uparrow(\mathrm{P})$ & {$[44,45,47]$} \\
\hline Sult1d1 & $\downarrow \leftrightarrow(\mathrm{M})$ & & & {$[15,44,45]$} \\
\hline Sult1e1/SULT1E1 & $\leftrightarrow\left(\partial^{\lambda} \mathrm{M}\right)$ & & $\uparrow(\mathrm{M}, \mathrm{P}) \leftrightarrow(\mathrm{A})$ & {$[44,47,48,51]$} \\
\hline Sult2a1/SULT2A1 & $\downarrow(\mathrm{M})$ & & $\downarrow(\mathrm{P}, \mathrm{A})$ & {$[44,45,47,48,52,53]$} \\
\hline Sult3a1 & $\downarrow(\odot \mathrm{M}) \leftrightarrow\left(\circlearrowleft^{\lambda} \mathrm{M}\right)$ & & & {$[15,45]$} \\
\hline Papss2 & $\downarrow((\mathrm{M}) \leftrightarrow(\overbrace{}^{\lambda} \mathrm{M})$ & & & {$[45]$} \\
\hline \multicolumn{5}{|c|}{ Glutathione $S$-transferases } \\
\hline Gsta $1 / 2 /$ GSTA1/2 & $\downarrow(\mathrm{M})$ & $\downarrow(\mathrm{P})$ & $\downarrow(\mathrm{P})$ & {$[15,44,54-57]$} \\
\hline Gsta3 & $\downarrow(\mathrm{M})$ & & & {$[15,44,54]$} \\
\hline Gsta4 & $\downarrow(\mathrm{M})$ & & & {$[44,54]$} \\
\hline Gsta8 & & $\downarrow(\mathrm{P})$ & & {$[55]$} \\
\hline Gsta10 & & $\uparrow(\mathrm{P})$ & & {$[55]$} \\
\hline Gstk1 & $\downarrow(\mathrm{M})$ & & & {$[15,54]$} \\
\hline Gstm1/GSTM1 & $\downarrow \leftrightarrow(\mathrm{M})$ & $\downarrow(\mathrm{P})$ & $\uparrow(\mathrm{P})$ & {$[15,44,54-56]$} \\
\hline Gstm2 & $\downarrow(\mathrm{M})$ & & & {$[15,44,54]$} \\
\hline Gstm3 & $\downarrow \leftrightarrow(\mathrm{M})$ & $\downarrow(\mathrm{P})$ & & {$[15,44,54,55]$} \\
\hline Gstm4 & $\downarrow(\mathrm{M})$ & $\downarrow(\mathrm{P})$ & & {$[15,44,54,55]$} \\
\hline Gstm5 & $\uparrow(\mathrm{M})$ & & & {$[15,44,54]$} \\
\hline Gstm6 & $\downarrow \leftrightarrow(\mathrm{M})$ & & & {$[15,44,54]$} \\
\hline Gstm7 & $\downarrow\left(\mathrm{o}^{\lambda} \mathrm{M}\right)$ & & & [44] \\
\hline Gsto1 & $\downarrow(\mathrm{M})$ & & & {$[44,54]$} \\
\hline Gstp1/2/GSTP1 & $\downarrow(\mathrm{M})$ & & $\uparrow(\mathrm{P})$ & {$[15,44,54,56,57]$} \\
\hline Gstp7 & & $\uparrow(\mathrm{P})$ & & {$[55]$} \\
\hline Gstt1 & $\downarrow \leftrightarrow(\mathrm{M})$ & & & {$[15,44,54]$} \\
\hline
\end{tabular}


Table 3. Cont.

\begin{tabular}{|c|c|c|c|c|}
\hline Enzyme & Mouse & Rat & Human & References \\
\hline Gstt2 & $\leftrightarrow(\mathrm{M})$ & & & {$[15,44,54]$} \\
\hline Gstt3 & $\downarrow \leftrightarrow(\mathrm{M})$ & & & {$[15,44,54]$} \\
\hline Gstz1/GSTZ1 & $\downarrow(\mathrm{M})$ & & $\downarrow(\mathrm{P}, \mathrm{A})$ & {$[15,44,54,56]$} \\
\hline Mgst1 & $\downarrow(\mathrm{M})$ & & & {$[15,44]$} \\
\hline Mgst2 & $\uparrow \leftrightarrow(\mathrm{M})$ & & & {$[44,54]$} \\
\hline Mgst3 & $\downarrow \uparrow(\mathrm{M})$ & & & {$[15,44,54]$} \\
\hline \multicolumn{5}{|c|}{ UDP Glucuronosyltransferases } \\
\hline Ugt1a1/UGT1A1 & $\downarrow\left({ }^{\lambda} \mathrm{M}\right)$ & $\downarrow(\mathrm{M}, \mathrm{P}, \mathrm{A})$ & $\downarrow(\mathrm{A})$ & {$[44,58,59]$} \\
\hline UGT1A3 & & & $\downarrow(\mathrm{A})$ & [59] \\
\hline Ugt1a5 & $\downarrow(\lesssim \mathrm{M})$ & $\downarrow(\mathrm{M}, \mathrm{P})$ & & {$[44,58]$} \\
\hline Ugt1a6/UGT1A6 & $\downarrow(\lesssim \mathrm{M})$ & $\uparrow(\mathrm{M}, \mathrm{P})$ & $\downarrow(\mathrm{A})$ & {$[44,58,60]$} \\
\hline Ugt1a9 & $\downarrow(\lesssim \mathrm{M})$ & & & [44] \\
\hline Ugt2a3 & $\downarrow(\mathrm{M})$ & & & {$[15,44]$} \\
\hline Ugt2b1 & $\downarrow(\mathrm{M})$ & & & {$[15,44]$} \\
\hline Ugt2b5 & $\downarrow(\mathrm{M})$ & & & {$[15,44]$} \\
\hline UGT2B7 & & & $\downarrow(\mathrm{M}, \mathrm{A})$ & {$[61,62]$} \\
\hline UGT2B15 & & & $\downarrow(\mathrm{M})$ & {$[61]$} \\
\hline UGT2B17 & & & $\downarrow(\mathrm{M}, \mathrm{A})$ & {$[61,63]$} \\
\hline Ugt2b34 & $\downarrow \leftrightarrow(\mathrm{M})$ & & & {$[15,44]$} \\
\hline Ugt2b35 & $\downarrow(\mathrm{M})$ & & & {$[15,44]$} \\
\hline Ugt2b36 & $\downarrow(\mathrm{M})$ & & & {$[15,44]$} \\
\hline Ugt 2 b3 37 & $\downarrow \leftrightarrow(\mathrm{M})$ & & & {$[15,44]$} \\
\hline Ugt2b38 & $\downarrow\left({ }^{\lambda} \mathrm{M}\right)$ & & & {$[44]$} \\
\hline Ugt3a1 & $\downarrow \leftrightarrow(\mathrm{M})$ & & & {$[15,44]$} \\
\hline Ugt3a2 & $\downarrow(\mathrm{M})$ & & & {$[15,44]$} \\
\hline \multicolumn{5}{|l|}{$N$-Acetyltransferases } \\
\hline Nat1/NAT1 & $\downarrow(\mathrm{M}, \mathrm{A})$ & & $\leftrightarrow(\mathrm{A})$ & {$[44,64,65]$} \\
\hline Nat2 & $\downarrow(\mathrm{M}, \mathrm{A})$ & & & {$[44,64]$} \\
\hline Nat8 & $\downarrow\left({ }^{\Uparrow} \mathrm{M}\right)$ & & & {$[44]$} \\
\hline
\end{tabular}

${ }^{1}$ Expression or activity compared to adult liver levels. mRNA expression (M), protein expression (P), and activity (A) are noted; $\uparrow$ denotes up-regulation; $\downarrow$ denotes down-regulation; and $\leftrightarrow$ denotes no change. Specific data for females $(+)$ or males $\left({ }^{\Uparrow}\right)$ are noted. Human orthologs are indicated only for isoforms with human data.

\subsection{Sulfotransferase Enzymes}

SULTs detoxify chemicals through conjugation with a sulfate group from 3'-phosphoadenosine-5'phosphosulfate. Found largely in the cytosol, SULTs metabolize a wide variety of xeno- and endobiotics, including compounds containing alcohols, phenols, catechols, and amines. At this time, SULTs are thought to be the prevailing drug metabolizing enzymes in the fetal liver (reviewed in [66]). SULTs are responsible for the metabolism of hormones and steroids. In some cases, rodents and humans express distinctive isoforms based on their differing hormonal and steroidal profiles. An example of this is SULT2A1, the only SULT that conjugates hydroxysteroids in humans, while multiple isoforms accomplish this function in rodents [66]. 


\subsubsection{Mouse Sult Regulation}

Sult mRNAs are expressed to varying degrees in the livers of adult mice. For example, there is high (Sult2a1/2, Sult3a1), moderate (Sult1a1, 1d1) and low enrichment (Sult1c1, Sult4a1, Sult5a1) of Sults [45]. Compared to adult mice, the livers of fetal mice only contain a subset of Sult isoforms, primarily, Sult1a1, which has a fairly broad substrate profile. Sult1a1 mRNA is present in the fetal liver and its expression continues to increase postnatally [45]. Sult1c1 mRNA is also expressed in liver two days prior to birth and decreases thereafter.

\subsubsection{Human SULT Regulation}

Compared to mice, humans exhibit more extensive expression of SULT isoforms in the fetal versus the adult liver. One such isoform is SULT1A3, which sulfonates catecholamines. SULT1A3 protein is high in the fetal liver but absent from the adult liver [46]. Specifically, it has been demonstrated that hepatic SULT1A3 can conjugate the neurotransmitter dopamine during the second trimester [47]. Another example of species differences in phase II ontogeny is SULT1C1/Sult1c1. As mentioned above, Sult1c1 mRNA is present to a limited degree in the fetal mouse liver. SULT1C1 mRNA has not been significantly detected in the fetal human liver [46,67]. Rather, SULT1C2 appears to be the fetal-enriched SULT1C isoform in humans [47].

Liver has the highest level of steroid-sulfonating enzymes of any adult human tissue, however, this may not be the case in the fetus. During pregnancy, the fetal-placental unit converts dehydroepiandrosterone to a pregnancy-specific estrogen, estriol, which then circulates in maternal blood. The fetal hepatic expression of the dehydroepiandrosterone sulfotransferase, SULT2A1, is second to that of the fetal adrenal glands, although expression and catalytic activity toward its probe substrate are still significant $[47,48,52,53,68]$. Like SULT2A1, SULT1A1 protein is also substantial in the fetal liver $[47,48]$. SULT1A1 is found in hematopoietic cells and both fetal and adult hepatocytes, with higher detection in prenatal samples [46,47]. Moreover, the biological activity of both endo- and exogenous estrogens can be terminated with metabolism by SULT1E1. Fetal protein expression and activity of the estrogen SULT has also been detected at equivalent or even higher levels than in adult liver, which may reflect the need for greater hormone metabolism in utero or to compensate for the lack of other sulfonation enzymes prenatally [47,48,51].

\subsection{Glutathione S-Transferase Enzymes}

GSTs are found in both the cytosol and endoplasmic reticulum, and catalyze the addition of the tripeptide glutathione (glycine-cysteine-glutamate) to substrates. Glutathione is an important defense in the cell for neutralizing electrophiles, protecting the cell from harmful reactive oxygen species, such as free radicals and organic hydroperoxides, and in the body for drug detoxification. While the developmental pattern of glutathione conjugation by GSTs in humans varies according to the isoform, it is generally one of the last phase II enzyme classes to mature, which does not fully occur until adolescence (9 to 12 years). 


\subsubsection{Mouse Gst Regulation}

Of the 19 identified mouse Gst isoforms, the adult liver expresses cytosolic Gsta3, Gstm1, m4, and m6, Gstp1/2 (greater in males), Gstt1 and Gstz1 as well as mitochondrial Gtsk1 and microsomal MGst1 $[69,70]$. The fetal liver has detectable quantities of each of these isoforms, albeit with very low content $(<20 \%)$ [54]. In addition, fetal mouse hepatocytes highly express Gstm5 and Mgst2 transcripts, which become barely detectable around postnatal day 15 [54].

\subsubsection{Rat Gst Regulation}

The adult rat liver is enriched with Gsta1, a2, a8 and Gstm3, m4 protein [55]. One day prior to birth, the rat fetal liver exhibits significant Gst activity (78\% of adult liver) towards the probe substrate 2-mercaptoethanol, 1-chloro-2,4-dinitrobenzene, before a transient decline postnatally and gradual increase to maximal function [55]. Using liquid chromatography, Gst subunits purified from fetal rat liver have been studied. The protein isoforms of highest proportion detected in gestational tissues were Gsta2 and Gstm3 [55]. In addition, while Gsta10 is lowly expressed in the adult liver, it is elevated in the fetal liver. Likewise, Gstp7 is present in the fetal liver and barely detectable after birth [55].

\subsubsection{Human GST Regulation}

Little is known about the amount and activity of GST enzymes in the fetal human liver. A small study with tissues from two first trimester pregnancies (an embryo at 8 weeks gestation and a fetus at 13 weeks gestation) has characterized several GST subfamilies by western blot. Whereas GSTP1 was the most highly expressed GST protein throughout the fetus, including the liver, GSTA protein was the second most abundant isoform specifically found in the liver [56]. The same study also found significant protein levels of GSTM1 in the fetal liver [56]. A different study comprised of 61 prenatal samples from 10 weeks of gestation and older found that similar to fetal mouse liver, human GSTZ1 protein is marginally expressed and minimally active, with a significant increase seen at birth [71].

\subsection{UDP-Glucuronosyltransferase Enzymes}

UGTs are localized to the endoplasmic reticulum, and account for nearly half of total hepatic conjugation reactions in the adult [72]. UGTs catalyze the addition of glucuronic acid to a wide variety of small hydrophobic molecules. In both rodents and humans, UGTs are repressed in the fetal liver. For example, human fetal livers (first trimester) have 13 to 36 times less UGT2B mRNA than adult livers [61]. Rat Ugtla6 is one exception to this trend. Hepatic Ugtla6 protein is first detected 5 days prior to birth and is the most highly expressed fetal Ugt near parturition [58]. Kishi et al. (2008) have proposed that there is a "switch" at birth from the prenatally-enriched rat Ugtla6 to the postnatally-enhanced rat Ugt1a1 isoform. This perinatal shift is apparent in the change of activity from phenol glucuronidation to bilirubin glucuronidation, however the molecular mechanism(s) underlying this transition is not known [58]. 


\subsection{N-Acetyltransferase Enzymes}

In the cytosol, NATs conjugate primary aryl amines with an acetyl group. Common drugs acetylated by NATs include the anti-tuberculosis drug isoniazid and sulfonamide antibiotics. Temporal development of acetylation is second to sulfation in humans, and is fully mature in the newborn infant. Adult mouse hepatocytes only express mRNA for Nat2. Similarly, although both Nat1 and Nat2 transcripts are found in the mouse fetus, fetal hepatocytes only contain Nat2 [64,73]. The ability of NAT to acetylate $p$-aminobenzoic acid has been detected in the human liver during the first trimester, however the responsible isoform(s) was not determined [65]. It is hypothesized that this phase II enzyme is critical during development because it acetylates a folate breakdown product, which ensures the turnover of folate within the embryo and prevents deficiency [73].

\subsection{Absolute Phase II Enzyme Expression in Fetal and Neonatal Mouse Liver}

Lu et al. (2013) recently described the ontogeny of hepatic phase II enzyme families in mice using RNA-Sequencing. Prior to birth, Gsts are the highest mRNAs detected in mouse liver. The profiles for Sults are largely unchanged between fetal and adult livers, such that Sult1a1 was shown to be the predominant isoform, accounting for more than $80 \%$ of total Sult transcripts [44]. It should be noted that there is a surge in Sult mRNAs between postnatal days 15 to 25 followed by a decline to adult levels. While there is some overlap in fetal and adult isoforms, mGst3 is the most abundant Gst mRNA in fetal liver, as opposed to mGst1 in adult liver [44]. Gstp1, $\mathrm{t} 1$ and $\mathrm{m} 1 \mathrm{mRNAs}$ are also highly expressed in fetal liver [44]. Although the absolute expression of Ugts is quite low prior to birth, some isoforms can be detected. Two days before birth, mouse livers are most highly enriched with members of the Ugt2b family, including Ugt2b34, followed by Ugt2b35, $2 b 36$ and 2b5 [44]. At birth, Ugt1a1 expression transiently surges and accounts for more than a third of Ugt total transcripts, however Ugt $2 b$ family isoforms are extensively found in the adult livers, particularly Ugt2b5, 2 b36 and 2b1 [44].

In addition to phase I drug metabolizing enzymes, RNA-Sequencing data of human fetal livers also revealed low (GSTA5, NAT2, SULT6B1, SULT1B1, SULT1C3, UGT2A1, UGT2B17, UGT1A1-10) and high (GSTA1, GSTP1, GSTO1, MGST3, MGST1, MGST2, SULT1A1, UGT2B10, UGT2B4) expression patterns of certain phase II drug metabolizing enzymes [38].

\subsection{Potential Mechanisms for the Regulation of Phase II Metabolism during Ontogeny}

Epigenetic programming has been postulated as a mechanism for regulating the ontogeny of Gsts. In a recent study, Gstz1 was studied as a target of epigenetic regulation because it is expressed most highly in the adult mouse liver, and minimally in the fetal liver. Histone 3 lysine-4 dimethylation confers an open chromatin conformation and thus accessible gene promoter regions, and is associated with active transcription. Cui et al. (2010) found minimal histone 3 lysine-4 dimethylation in the Gstz1 gene locus two days prior to birth, when mRNA levels are low [54]. After birth, levels of this epigenetic mark as well as Gstzl mRNA increase. This study is an intriguing example of how epigenetic factors may repress phase II metabolism prenatally. There is great potential to expand this work to other enzyme isoforms and classes. 
The expression of several of the phase II isozymes has been shown to be sex- and species-specific [45,69,74-76]. For example, Sult1a1 is significantly higher in the livers of female mice, while the opposite is true for the livers of rats [45,76]. Nevertheless, it is not known whether these differences are initiated during fetal development. Sult2a1/2 and Sult3a1 are almost exclusively present in the livers of adult female mice, while this sex difference has not been seen in fetal livers [45]. Likewise, sex differences observed for Gst mRNAs in the livers of adult mice have not been detected in mouse livers two days before birth [54]. A unique exception to this is the expression of human SULT1E1, a key mechanism for fetal estrogen inactivation. Duanmu et al. (2006) found early prenatal male liver expression of this isoform to be consistently higher than that of females [48]. This exception would appear to have a defining role in proper male development rather than differential drug metabolizing profiles between genders.

Other sulfotransferases involved in hormone metabolism, and also highly expressed in the fetal liver, appear to have differing patterns of enrichment throughout gestation. SULT1A1 protein is consistent throughout gestation, while SULT2A1 protein increases during the third trimester [48]. Although relatively unexplored, this observation indicates differential regulatory mechanisms of these key enzymes during development. Thus far, the nuclear receptor Pxr has been implicated in the regulation of rodent Sult2a1 [77], while PPAR $\alpha$ has been implicated in regulation of the human isoform [78]. In addition, transcription factors Specificity Protein 1 and E-Twenty Six regulate human SULT1A1 [79]. While these transcription factors play a role in regulating Sults/SULTs in adult liver, their ability to control the ontogenic expression is unknown.

\section{Transporters}

Transport and biliary excretion are key functions of the liver that mature during development. The liver expresses a number of proteins that regulate the uptake and efflux of exogenous and endogenous organic anions and organic cations in a coordinated manner (Figure 1). Similar to phase I and II enzymes, studies investigating the fetal expression of transporters in rodents and humans have largely focused on characterization of mRNA levels during the perinatal period although studies have begun to document the ability of fetal human hepatocytes to transport bile acids and drugs (Table 4).

Figure 1. Subcellular localization of transporters in hepatocytes. The localization and orientation of uptake and efflux transporters (primarily rodent isoforms) at the sinusoidal and canalicular plasma membranes are shown.

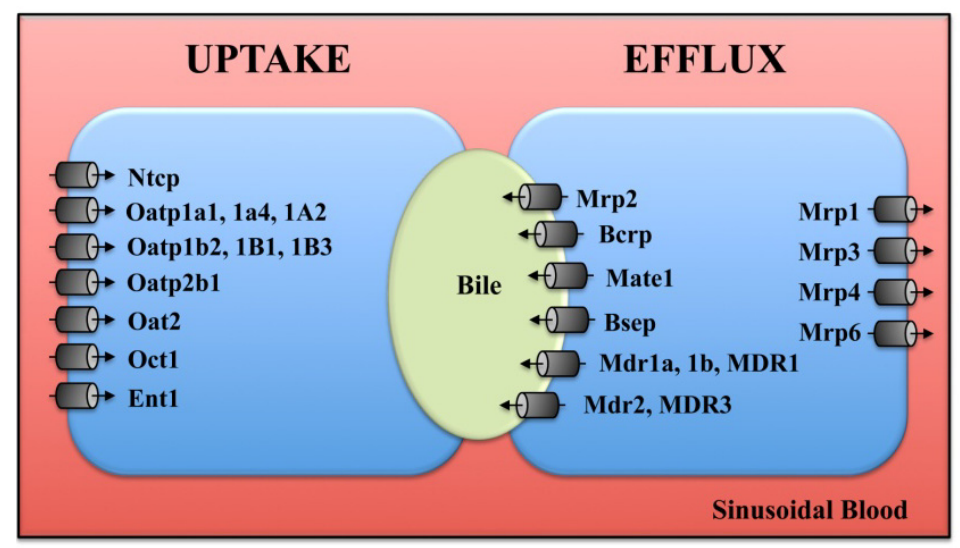


Table 4. Transport in rodent and human fetal livers. ${ }^{1}$

\begin{tabular}{|c|c|c|c|c|}
\hline Transporter & Mouse & Rat & Human & References \\
\hline \multicolumn{5}{|l|}{ Uptake Transporters } \\
\hline Slc1a5 & $\uparrow(\mathrm{M})$ & & & {$[15]$} \\
\hline Slc2a1 & $\uparrow(\mathrm{M})$ & & & {$[15]$} \\
\hline Slc2a3 & $\uparrow(\mathrm{M})$ & & & [15] \\
\hline Slc3a2 & $\uparrow(\mathrm{M})$ & & & [15] \\
\hline Slc4a1 & $\uparrow(\mathrm{M})$ & & & {$[15]$} \\
\hline Slc6a9 & $\leftrightarrow(\mathrm{M})$ & & & {$[15]$} \\
\hline Slc7a1 & $\uparrow \leftrightarrow(\mathrm{M})$ & & & [15] \\
\hline Slc7a5 & $\uparrow(\mathrm{M})$ & & & {$[15]$} \\
\hline Slc10a1/Ntcp/NTCP & $\downarrow(\mathrm{M}, \mathrm{P})$ & $\downarrow(\mathrm{M}, \mathrm{P})$ & $\downarrow(\mathrm{M})$ & {$[22,80-85]$} \\
\hline Slc10a2/Asbt & $\downarrow(\mathrm{M})$ & & & {$[80]$} \\
\hline Slc14a1 & $\uparrow(\mathrm{M})$ & & & [15] \\
\hline Slc16a1 & $\uparrow(\mathrm{M})$ & & & [15] \\
\hline Slc17a1/Npt1 & $\downarrow(\mathrm{M})$ & & & [80] \\
\hline Slc20a1 & $\uparrow(\mathrm{M})$ & & & {$[15]$} \\
\hline Slc22a1/Oct1 & $\downarrow(\mathrm{M})$ & $\downarrow(\mathrm{M})$ & & {$[7,22,80,86]$} \\
\hline Slc22a2/Oct2 & & $\uparrow(\uparrow \mathrm{M}) \downarrow\left(\partial^{\lambda} \mathrm{M}\right)$ & & [7] \\
\hline Slc22a4/Octn1 & $\uparrow(\mathrm{M})$ & & & [80] \\
\hline Slc22a5/Octn2 & $\leftrightarrow(\mathrm{M})$ & & & [80] \\
\hline Slc22a6/Oat1 & & $\downarrow(\mathrm{M})$ & & [7] \\
\hline Slc22a7/Oat2 & $\downarrow(\mathrm{M})$ & $\downarrow(\mathrm{M})$ & & {$[7,22,80,85]$} \\
\hline Slc22a8/Oat3 & $\uparrow(\mathrm{M})$ & $\uparrow(\mathrm{M})$ & & {$[7,80]$} \\
\hline Slc25a 4 & $\uparrow(\mathrm{M})$ & & & {$[15]$} \\
\hline Slc25a37 & $\uparrow(\mathrm{M})$ & & & [15] \\
\hline Slc25a38 & $\leftrightarrow(\mathrm{M})$ & & & {$[15]$} \\
\hline Slc29a1/Ent1 & $\leftrightarrow(\mathrm{M})$ & & & {$[22,80]$} \\
\hline Slc29a3/Ent3 & $\leftrightarrow(\mathrm{M})$ & & & {$[80]$} \\
\hline Slc38a1 & $\uparrow(\mathrm{M})$ & & & [15] \\
\hline Slc38a5 & $\uparrow(\mathrm{M})$ & & & {$[15]$} \\
\hline Slc39a5 & $\uparrow(\mathrm{M})$ & & & {$[15]$} \\
\hline Slc39a8 & $\leftrightarrow(\mathrm{M})$ & & & [15] \\
\hline Slc43a1 & $\uparrow(\mathrm{M})$ & & & {$[15]$} \\
\hline Slc43a3 & $\uparrow(\mathrm{M})$ & & & {$[15]$} \\
\hline Slc47a1/Mate1 & $\downarrow(\mathrm{M})$ & & & {$[22,80]$} \\
\hline Slc51a/Ost $\alpha$ & $\leftrightarrow(\mathrm{M})$ & & & [22] \\
\hline Slc51b/Ost $\beta$ & $\leftrightarrow(\mathrm{M})$ & & & {$[22,80]$} \\
\hline Slco1a1/Oatp1a1 & $\downarrow(\mathrm{M})$ & $\downarrow\left(\mathrm{M}, \partial^{\wedge} \mathrm{P}\right)$ & & {$[22,80,81,85,87]$} \\
\hline Slco1a4/Oatp1a4 & $\downarrow \leftrightarrow(\mathrm{M})$ & $\uparrow \downarrow(\mathrm{M}) \downarrow\left(\jmath^{\lambda} \mathrm{P}\right)$ & & {$[7,22,80,81,87]$} \\
\hline Slco1a6/Oatp1a6 & $\leftrightarrow(\mathrm{M})$ & & & [87] \\
\hline SLCO1B1/OATP1B1 & & & $\downarrow(\mathrm{M})$ & [83] \\
\hline Slco1b2/Oatp1b2 & $\downarrow(\mathrm{M})$ & $\downarrow\left(\mathrm{M}, O^{\wedge} \mathrm{P}\right)$ & & {$[22,80,81,85,87]$} \\
\hline SLCO1B3/OATP1B3 & & & $\downarrow(\mathrm{M})$ & {$[83]$} \\
\hline Slco4a1/Oatp4a1 & & $\downarrow(\mathrm{M})$ & & {$[85]$} \\
\hline Slco2a1/Oatp2a1 & $\downarrow \leftrightarrow(\mathrm{M})$ & & & {$[80,87]$} \\
\hline Slco2b1/Oatp2b1/2B1 & $\downarrow(\mathrm{M})$ & $\downarrow(\mathrm{M})$ & $\downarrow(\mathrm{M})$ & {$[22,80,83,85,87]$} \\
\hline
\end{tabular}


Table 4. Cont.

\begin{tabular}{ccccc}
\hline Transporter & Mouse & Rat & Human & References \\
\hline Efflux Transporters & & & & \\
\hline Abca1 & $\uparrow \leftrightarrow(\mathrm{M})$ & & & {$[22,80]$} \\
ABCB1/MDR1 & & $\downarrow(\mathrm{M}, \mathrm{P})$ & {$[83,88]$} \\
Abcb1a/Mdr1a & & $\downarrow \leftrightarrow(\mathrm{M})$ & & {$[7,89]$} \\
Abcb1b/Mdr1b & $\leftrightarrow(\mathrm{M})$ & $\downarrow(\mathrm{M})$ & & {$[7,89,90]$} \\
Abcb4/Mdr2/MDR3 & $\downarrow \leftrightarrow(\mathrm{M})$ & & $\downarrow(\mathrm{M}, \mathrm{P})$ & {$[22,80,82,83,90]$} \\
Abcb10 & $\uparrow(\mathrm{M})$ & & \\
Abcb11/Bsep/BSEP & $\downarrow \leftrightarrow(\mathrm{M}) \downarrow(\mathrm{P})$ & $\uparrow \downarrow(\mathrm{M}, \mathrm{P})$ & $\downarrow(\mathrm{M}, \mathrm{P})$ & {$[7,22,80-83,85,91]$} \\
Abcc1/Mrp1 & $\uparrow(\mathrm{M})$ & $\uparrow(\mathrm{M})$ & & {$[7,80,85,89]$} \\
Abcc2/Mrp2/MRP2 & $\downarrow(\mathrm{M})$ & $\downarrow \leftrightarrow(\mathrm{M}, \mathrm{P})$ & $\downarrow(\mathrm{M}, \mathrm{P})$ & {$[7,22,80-83,85,89,91,92]$} \\
Abcc3/Mrp3/MRP3 & $\downarrow(\mathrm{M})$ & $\uparrow \leftrightarrow(\mathrm{M})$ & $\downarrow(\mathrm{M})$ & {$[7,22,80,83,85,92]$} \\
Abcc4/Mrp4/MRP4 & $\uparrow \leftrightarrow(\mathrm{M})$ & & $\leftrightarrow(\mathrm{M})$ & {$[22,80,83,92]$} \\
Abcc5/Mrp5 & $\uparrow(\mathrm{M})$ & & & {$[80]$} \\
Abcc6/Mrp6 & $\downarrow(\mathrm{M})$ & $\uparrow \downarrow(\mathrm{M}) \downarrow\left({ }^{\top} \mathrm{P}\right)$ & & {$[7,22,80,81,85,92]$} \\
Abcg2/Bcrp/BCRP & $\uparrow \leftrightarrow(\mathrm{M})$ & $\uparrow(\mathrm{M})$ & $\downarrow \leftrightarrow(\mathrm{M})$ & {$[7,15,22,80,83]$} \\
Abcg5 & $\downarrow \leftrightarrow(\mathrm{M})$ & & & {$[22,80]$} \\
Abcg8 & $\leftrightarrow(\mathrm{M})$ & & & {$[22,80]$} \\
Atp7b & $\uparrow(\mathrm{M})$ & & & {$[80]$} \\
Atp8b1 & $\downarrow(\mathrm{M})$ & & {$[22]$} \\
\hline
\end{tabular}

${ }^{1}$ Expression or activity compared to adult liver levels. mRNA expression (M), protein expression (P), and activity (A) are noted; $\uparrow$ denotes up-regulation; $\downarrow$ denotes down-regulation; and $\leftrightarrow$ denotes no change. Specific data for females $(+)$ or males $(\hat{\jmath})$ are noted. Human orthologs are indicated only for isoforms with human data.

\subsection{Uptake Transporters}

\subsubsection{Mouse and Rat Uptake Transporter Regulation}

The influx of positively-charged chemicals into the liver is accomplished by the organic cation transporter 1 (Oct1, Slc22a1). Oct1 mRNA is undetectable in fetal mouse hepatocytes $[80,86]$. It is not until birth (designated as postnatal day 0) that Oct1 mRNA is first detected at $\sim 10 \%$ of adult transcripts [86]. A similar delay in establishment of Oct1 mRNA expression has been observed in rat liver after birth [7]. It is presumed that there is minimal organic cation transport in the prenatal liver; however, further functional studies are needed to test this hypothesis.

The liver expresses a number of organic anion transporters (Oats) and organic anion transporting polypeptides (Oatps) that are responsible for the uptake of chemicals into hepatocytes and biliary cells using sodium-independent transport. In general, Oatp mRNAs are quite low in rodent liver prior to birth $[81,87,93]$. mRNA of mouse Oatp2a1 (Slco2a1), which is also termed the prostaglandin transporter, is moderately expressed in late gestation that does not change during postnatal development [87]. At parturition, Oatp1b2 mRNA is induced which is followed by significant rises in Oatp1a1, 1a4, and 2b1 between postnatal days 5 and 30 in mice and rats [7,80,81,87,94]. Weak intracellular staining of Oatpla1 protein can be observed in the newborn rat liver; however, trafficking to the sinusoidal membrane of hepatocytes is not observed until 20 days after birth [81]. In fetal rat 
liver, Oat3 (Slc22a8) mRNA is detected at levels higher than observed in adults, whereas Oat2 (Slc22a7) mRNA is not observed until postnatal days 5 to 15 [7,80]. Collectively, these data suggest that establishment of the majority of Oat- and Oatp-mediated transport occurs after birth and that Oat 3 may be the primary organic anion uptake transporter in the fetal liver.

While the gene expression of Oatp, Oat, and Oct is relatively low in the mouse fetal liver, it should be noted that the mRNA of equilibrative nucleoside transporter 1 (Ent1, Slc29a1) has been detected [22]. Ent1 transports nucleosides that may be important in the proliferation and maturation of the liver. While Ent1 is modestly expressed in the fetal liver, this transporter continues to increase postnatally with maximal expression at postnatal day 20 [80].

\subsection{Efflux Transporters}

\subsubsection{Rodent and Human Efflux Transporter Regulation}

Multidrug resistance (Mdr) transporters are responsible for the canalicular secretion of amphipathic molecules and cations (Mdr/Abcb1a and 1b isoforms in rodents and MDR1 in humans, also known as P-glycoprotein) and phospholipids (Mdr2/Abcb2 isoform in rodents and MDR3 in humans). Mdr1a and $1 \mathrm{~b}$ mRNA are low in the fetal rat liver, relative to the adult $[7,89]$. The human MDR1 protein can be detected along the canalicular membrane of fetal livers beginning at gestation week 13 and is maintained throughout fetal development [88]. Quantification of MDR1 mRNA in 12 fetal human livers has revealed significant increases from 15 to 27 weeks, with a subsequent decline at 42 weeks [95]. Interestingly, there is a transient mRNA "surge" in Mdr2 at birth in mice [22,90]. This increase in Mdr2 mRNA is attenuated in mice lacking the bile acid nuclear receptor, Fxr, suggesting that establishment of bile acid signaling, in part, stimulates Mdr2 up-regulation in neonatal mice [22]. Expression of the human ortholog MDR3 mRNA and protein in fetal livers is relatively low and most immunostaining is observed in the intracellular compartment, with only occasional canalicular staining at the plasma membrane [82]. At this time, it is unclear whether MDR3 mRNA is enhanced at birth similar to Mdr2.

The excretion of organic anions from the liver is primarily performed by the multidrug resistance-associated proteins (Mrps, Abcc gene family). Mrps are located on both the sinusoidal (Mrp/Abcc 1, 3, 4, 6) and canalicular (Mrp2/Abcc2) plasma membrane (reviewed in [96]). Mrp2 mRNA and protein as well as Mrp6 mRNA is detected in the fetal rat liver at gestation days 16-20 at approximately $10 \%$ of adult levels and increase to $27 \%$ to $40 \%$ by birth $[81,91,97]$. The timing of induction for these two transporters in mouse liver is somewhat different. The expression of Mrp2 mRNA in the fetal mouse liver is approximately $25 \%$ of that seen in the adult and reaches $100 \%$ at birth [92]. Similarly, human MRP2 mRNA is roughly 50\% in fetal livers compared to adult livers [82]. Immunostaining of MRP2 protein in fetal hepatocytes has been demonstrated as primarily on the canalicular plasma membrane, consistent with adult localization [82].

In mice, Mrp6 mRNA is not detected until postnatal day 10. At this age, the expression of Mrp6 actually exceeds adult levels by 3-fold [92]. The amount of Mrp4 mRNA in the fetal mouse liver is similar to the adult, although there is a transient increase at birth [92,94]. By contrast, Mrp3 mRNA is low in the fetal liver and complete establishment is not observed until 20 to 30 days after birth [80,92,94]. 
Because of the divergent patterns in the expression of various hepatic Mrps, it is likely that there are differing regulatory mechanisms for each isoform.

The breast cancer resistance protein (Bcrp/Abcg2) is an additional efflux transporter that is responsible for the canalicular excretion of drugs and endogenous chemicals. Interestingly, Bcrp mRNA is highest in mouse and rat fetal livers and decreases during ontogeny [7,22]. This is an important observation and may reflect the fact that the fetal liver is primarily a hematopoetic tissue since Bcrp is an important marker of hematopoiesis [98].

\subsection{Bile Acid Transporters}

\subsubsection{Rodent and Human Bile Acid Transporter Regulation}

Bile acid production and handling are initiated in mouse and rat liver at birth and increase steadily during the postnatal period $[23,80]$. Between postnatal day 1 and 45 , taurocholate is the predominant bile acid in serum and liver [22]. The vectoral secretion of bile acids into bile is coordinated primarily by two transporters, the sinusoidal uptake transporter, sodium taurocholate co-transporting polypeptide (Ntcp/Slc10a1) and the canalicular efflux transporter, bile salt export pump (Bsep/Abcb11) [96] (Figure 1). Ntcp mRNA is absent through most of fetal development in the rat and is first detected at the end of gestation (gestation days 18-21) [99] when sodium-dependent uptake of the bile acid taurocholate can be quantified in vesicles prepared from rat liver sinusoidal plasma membranes [100]. Likewise, taurocholate uptake and efflux in a temperature-dependent manner can be observed in human hepatocytes cultured from fetal livers [83]. Gene expression of human BSEP and NTCP has been observed in fetal hepatocytes although at approximately $50 \%$ and less than $10 \%$ of the adult, respectively [83]. Following birth, Ntcp and Bsep mRNA and protein dramatically increase on postnatal days 0 to 1 in mice [80] and rats [81,84,97]. Both proteins can be seen just prior to birth, however, transporter immunostaining that is similar to adults is not observed until postnatal days 5 (Ntcp) and 12 (Bsep) [81]. It should be noted that other studies have not been able to detect Bsep protein in the fetal rat liver [91,97]. Similar to Ntcp and Bsep, the organic solute transporter beta (Ost $\beta$ ), which transports bile acids in bile ducts, also exhibits a postnatal day 1 surge in expression in mice [22].

\subsection{Absolute Transporter Expression in Fetal and Neonatal Livers}

A recent study has quantified the absolute transcript levels of transporters in mouse liver using RNA-Sequencing and revealed that there is a similar number of uptake and efflux transporter mRNAs in the fetal liver (late gestation) [80]. At birth and over the following 3 weeks, mRNA levels of uptake transporters steadily increase, whereas only modest increases are observed in efflux transporter transcripts over the same time period [80]. Interestingly, the two most predominant transporter mRNAs in fetal mouse livers are Ent1 (29\% of total transporter mRNAs) and Bcrp (25\%) [80]. The absolute expression of other transporters in the fetal liver are modest and include Ntcp (6\%), Mdr2 (6\%), Oatp2a1 (4\%), Mrp3 (3\%), Mrp2 (3\%), Mrp6 (2\%), Bsep (2\%) [80]. By parturition, there is a shift in the absolute expression of transporter mRNAs with Ntcp mRNA comprising 52\% of total transporter mRNAs [80]. This is followed by Mdr2 (7\%), Ent1 (6\%), Mrp2 (5\%), Bcrp (4\%) and 
Bsep (4\%) [80]. Other transporters that appear to be enriched during the perinatal period include the multidrug and toxin extrusion 1 (Mate1) transporter, cholesterol transporter Abca1, the carnitine transporter Octn1, Oat3, Ent3 as well as Mrp1, 4, and 5.

\subsection{Potential Ontogenic Mechanisms for Bile Acid Transporter Regulation}

The marked increase in the expression of bile acid transporters at birth occurs in parallel with mRNA induction of transcription factors including Fxr (transcript variant 3) and its target gene, the short heterodimer partner, as well as Pxr [22]. Interestingly, mice lacking Fxr exhibit attenuated up-regulation of Ntcp, Bsep, and Ost $\beta$ mRNAs at birth suggesting a critical role for this transcription factor in the initiation of bile acid transporter expression [22]. Notably, no differences in bile acid transporter expression on postnatal day 1 were observed in Pxr-null mice [22], further supporting a more critical role for Fxr in the establishment of bile acid transport at birth.

\section{Conclusions and Future Directions}

The initiation and establishment of phase I, II, and transport pathways in the liver occurs in stages, often comprised of specific enzyme and transporter isoforms. Some enzymes and transporters exhibit modest expression in the fetal livers while others rapidly increase or "surge" at birth. Figure 2 illustrates the highest expressing enzymes and transporters based on RNA-Sequencing. Yet, others are not present until the postnatal, adolescent, or adult periods. As a result, there is immaturity of a number of key metabolic and disposition pathways during early development. Typically, the maternal excretory organs and the placenta will aid in protecting vulnerable fetuses until they begin to express a full complement of hepatic enzymes and transporters.

Figure 2. Enzymes and transporters expressed in the fetal mouse liver. RNA-sequencing studies have quantified the absolute mRNA expression of drug metabolizing and transport genes in the mouse fetal liver two days prior to birth $[3,14,44,80]$.

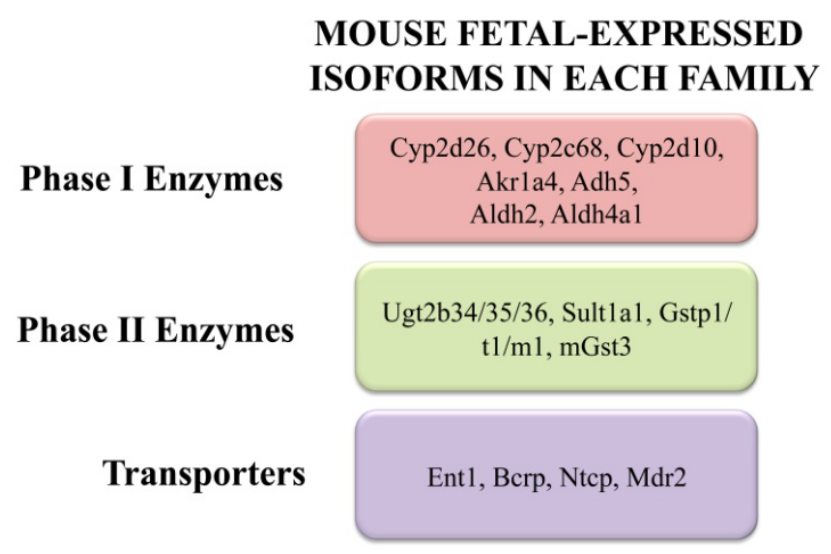

Current data suggest that the ontogeny of metabolizing enzymes and transporters is regulated by a combination of epigenetic (DNA methylation and histone modifications), transcriptional (nuclear receptors, transcription factors), and post-transcriptional mechanisms. Regulation can also be family-, subfamily-, or isoform-specific. Still, additional research is needed to more definitively 
understand these control mechanisms and to begin to probe novel regulator factors such as Hnfs, which are liver-specific transcription factors that develop early in gestation [41,101]. This will likely require greater utilization of translational approaches, including human fetal tissue banks as well human embryonic stem cells that can be differentiated into hepatocytes.

\section{Acknowledgments}

This work was supported by the National Institutes of Environmental Health Sciences (Grants ES020522, ES005022, ES007148), a component of the National Institutes of Health. Jamie Moscovitz is supported by a predoctoral fellowship from the American Foundation for Pharmaceutical Education.

\section{Conflicts of Interest}

The authors declare no conflict of interest.

\section{References}

1. Fouts, J.R.; Adamson, R.H. Drug metabolism in the newborn rabbit. Science 1959, 129, 897-898.

2. Alnouti, Y.; Klaassen, C.D. Tissue distribution, ontogeny, and regulation of aldehyde dehydrogenase (Aldh) enzymes mRNA by prototypical microsomal enzyme inducers in mice. Toxicol. Sci. 2008 , 101, 51-64.

3. Peng, L.; Cui, J.Y.; Yoo, B.; Gunewardena, S.S.; Lu, H.; Klaassen, C.D.; Zhong, X.B. RNA-sequencing quantification of hepatic ontogeny of phase-I enzymes in mice. Drug Metab. Dispos. 2013, 41, 2175-86.

4. Cherrington, N.J.; Cao, Y.; Cherrington, J.W.; Rose, R.L.; Hodgson, E. Physiological factors affecting protein expression of flavin-containing monooxygenases 1, 3 and 5. Xenobiotica 1998, $28,673-682$.

5. Dolphin, C.T.; Cullingford, T.E.; Shephard, E.A.; Smith, R.L.; Phillips, I.R. Differential developmental and tissue-specific regulation of expression of the genes encoding three members of the flavin-containing monooxygenase family of man, FMO1, FMO3 and FM04. Eur. J. Biochem. 1996, 235, 683-689.

6. Yeung, C.K.; Lang, D.H.; Thummel, K.E.; Rettie, A.E. Immunoquantitation of FMO1 in human liver, kidney, and intestine. Drug Metab. Dispos. 2000, 28, 1107-1111.

7. De Zwart, L.; Scholten, M.; Monbaliu, J.G.; Annaert, P.P.; van Houdt, J.M.; van den Wyngaert, I.; de Schaepdrijver, L.M.; Bailey, G.P.; Coogan, T.P.; Coussement, W.C.; et al. The ontogeny of drug metabolizing enzymes and transporters in the rat. Reprod. Toxicol. 2008, 26, 220-230.

8. Yang, D.; Pearce, R.E.; Wang, X.; Gaedigk, R.; Wan, Y.J.; Yan, B. Human carboxylesterases HCE1 and HCE2: Ontogenic expression, inter-individual variability and differential hydrolysis of oseltamivir, aspirin, deltamethrin and permethrin. Biochem. Pharmacol. 2009, 77, 238-247.

9. Choudhary, D.; Jansson, I.; Schenkman, J.B.; Sarfarazi, M.; Stoilov, I. Comparative expression profiling of 40 mouse cytochrome P450 genes in embryonic and adult tissues. Arch. Biochem. Biophys. 2003, 414, 91-100. 
10. Nelson, D.R.; Zeldin, D.C.; Hoffman, S.M.; Maltais, L.J.; Wain, H.M.; Nebert, D.W. Comparison of cytochrome P450 (CYP) genes from the mouse and human genomes, including nomenclature recommendations for genes, pseudogenes and alternative-splice variants. Pharmacogenetics 2004, 14, 1-18.

11. Hart, S.N.; Cui, Y.; Klaassen, C.D.; Zhong, X.B. Three patterns of cytochrome P450 gene expression during liver maturation in mice. Drug Metab. Dispos. 2009, 37, 116-121.

12. Sonnier, M.; Cresteil, T. Delayed ontogenesis of CYP1A2 in the human liver. Eur. J. Biochem. 1998, 251, 893-898.

13. Choudhary, D.; Jansson, I.; Stoilov, I.; Sarfarazi, M.; Schenkman, J.B. Expression patterns of mouse and human CYP orthologs (families 1-4) during development and in different adult tissues. Arch. Biochem. Biophys. 2005, 436, 50-61.

14. Peng, L.; Yoo, B.; Gunewardena, S.S.; Lu, H.; Klaassen, C.D.; Zhong, X.B. RNA sequencing reveals dynamic changes of mRNA abundance of cytochromes P450 and their alternative transcripts during mouse liver development. Drug Metab. Dispos. 2012, 40, 1198-1209.

15. Lee, J.S.; Ward, W.O.; Knapp, G.; Ren, H.; Vallanat, B.; Abbott, B.; Ho, K.; Karp, S.J.; Corton, J.C. Transcriptional ontogeny of the developing liver. BMC Genomics 2012, 13, 33.

16. Omiecinski, C.J.; Hassett, C.; Costa, P. Developmental expression and in situ localization of the phenobarbital-inducible rat hepatic mRNAs for cytochromes CYP2B1, CYP2B2, CYP2C6, and CYP3A1. Mol. Pharmacol. 1990, 38, 462-470.

17. Borlakoglu, J.T.; Scott, A.; Henderson, C.J.; Wolf, C.R. Expression of P450 isoenzymes during rat liver organogenesis. Int J. Biochem. 1993, 25, 1659-1668.

18. Koukouritaki, S.B.; Manro, J.R.; Marsh, S.A.; Stevens, J.C.; Rettie, A.E.; McCarver, D.G.; Hines, R.N. Developmental expression of human hepatic CYP2C9 and CYP2C19. J. Pharmacol. Exp. Ther. 2004, 308, 965-974.

19. De Wildt, S.N.; Kearns, G.L.; Leeder, J.S.; van den Anker, J.N. Cytochrome P450 3A: Ontogeny and drug disposition. Clin. Pharmacokinet 1999, 37, 485-505.

20. Lacroix, D.; Sonnier, M.; Moncion, A.; Cheron, G.; Cresteil, T. Expression of CYP3A in the human liver-Evidence that the shift between CYP3A7 and CYP3A4 occurs immediately after birth. Eur. J. Biochem. 1997, 247, 625-634.

21. Stevens, J.C.; Hines, R.N.; Gu, C.; Koukouritaki, S.B.; Manro, J.R.; Tandler, P.J.; Zaya, M.J. Developmental expression of the major human hepatic CYP3A enzymes. J. Pharmacol. Exp. Ther. 2003, 307, 573-582.

22. Cui, J.Y.; Aleksunes, L.M.; Tanaka, Y.; Fu, Z.D.; Guo, Y.; Guo, G.L.; Lu, H.; Zhong, X.B.; Klaassen, C.D. Bile acids via FXR initiate the expression of major transporters involved in the enterohepatic circulation of bile acids in newborn mice. Am. J. Physiol. Gastrointest Liver Physiol. 2012, 302, G979-996.

23. Cuesta de Juan, S.; Monte, M.J.; Macias, R.I.; Wauthier, V.; Calderon, P.B.; Marin, J.J. Ontogenic development-associated changes in the expression of genes involved in rat bile acid homeostasis. J. Lipid Res. 2007, 48, 1362-1370.

24. Li, X.Y.; Zhang, C.; Wang, H.; Ji, Y.L.; Wang, S.F.; Zhao, L.; Chen, X.; Xu, D.X. Tumor necrosis factor alpha partially contributes to lipopolysaccharide-induced downregulation of CYP3A in fetal liver: Its repression by a low dose LPS pretreatment. Toxicol. Lett. 2008, 179, 71-77. 
25. Blanco, J.; Mulero, M.; Domingo, J.L.; Sanchez, D.J. Gestational exposure to BDE-99 produces toxicity through upregulation of CYP isoforms and ROS production in the fetal rat liver. Toxicol. Sci. 2012, 127, 296-302.

26. Cresteil, T.; Beaune, P.; Kremers, P.; Celier, C.; Guengerich, F.P.; Leroux, J.P. Immunoquantification of epoxide hydrolase and cytochrome P-450 isozymes in fetal and adult human liver microsomes. Eur. J. Biochem. 1985, 151, 345-350.

27. Shimada, T.; Yamazaki, H.; Mimura, M.; Wakamiya, N.; Ueng, Y.F.; Guengerich, F.P.; Inui, Y. Characterization of microsomal cytochrome P450 enzymes involved in the oxidation of xenobiotic chemicals in human fetal liver and adult lungs. Drug Metab. Dispos. 1996, 24, $515-522$.

28. Treluyer, J.M.; Cheron, G.; Sonnier, M.; Cresteil, T. Cytochrome P-450 expression in sudden infant death syndrome. Biochem. Pharmacol. 1996, 52, 497-504.

29. Hines, R.N. Ontogeny of human hepatic cytochromes P450. J. Biochem. Mol. Toxicol. 2007, 21, 169-175.

30. Johnsrud, E.K.; Koukouritaki, S.B.; Divakaran, K.; Brunengraber, L.L.; Hines, R.N.; McCarver, D.G. Human hepatic CYP2E1 expression during development. J. Pharmacol. Exp. Ther. 2003, 307, 402-407.

31. Treluyer, J.M.; Jacqz-Aigrain, E.; Alvarez, F.; Cresteil, T. Expression of CYP2D6 in developing human liver. Eur. J. Biochem. 1991, 202, 583-588.

32. Cui, J.Y.; Renaud, H.J.; Klaassen, C.D. Ontogeny of novel cytochrome P450 gene isoforms during postnatal liver maturation in mice. Drug Metab. Dispos. 2012, 40, 1226-1237.

33. Li, Y.; Cui, Y.; Hart, S.N.; Klaassen, C.D.; Zhong, X.B. Dynamic patterns of histone methylation are associated with ontogenic expression of the Cyp3a genes during mouse liver maturation. Mol. Pharmacol. 2009, 75, 1171-1179.

34. Atterberry, T.T.; Burnett, W.T.; Chambers, J.E. Age-related differences in parathion and chlorpyrifos toxicity in male rats: Target and nontarget esterase sensitivity and cytochrome P450-mediated metabolism. Toxicol. Appl. Pharmacol. 1997, 147, 411-418.

35. Timchalk, C.; Poet, T.S.; Kousba, A.A. Age-dependent pharmacokinetic and pharmacodynamic response in preweanling rats following oral exposure to the organophosphorus insecticide chlorpyrifos. Toxicology 2006, 220, 13-25.

36. Xiao, D.; Chen, Y.T.; Yang, D.; Yan, B. Age-related inducibility of carboxylesterases by the antiepileptic agent phenobarbital and implications in drug metabolism and lipid accumulation. Biochem. Pharmacol. 2012, 84, 232-239.

37. Zhu, H.J.; Appel, D.I.; Jiang, Y.; Markowitz, J.S. Age- and sex-related expression and activity of carboxylesterase 1 and 2 in mouse and human liver. Drug Metab. Dispos. 2009, 37, 1819-1825.

38. Nahar, M.S.; Kim, J.H.; Sartor M.A.; Dolinoy, D.C. Bisphenol A-associated alterations in the expression and epigenetic regulation of genes encoding xenobiotic metabolizing enzymes in human fetal liver. Environ. Mol. Mutagen. 2013, in press.

39. Stoilov, I.; Akarsu, A.N.; Sarfarazi, M. Identification of three different truncating mutations in cytochrome P4501B1 (CYP1B1) as the principal cause of primary congenital glaucoma (Buphthalmos) in families linked to the GLC3A locus on chromosome 2p21. Hum. Mol. Genet. 1997, 6, 641-647. 
40. Balasubramaniyan, N.; Shahid, M.; Suchy, F.J.; Ananthanarayanan, M. Multiple mechanisms of ontogenic regulation of nuclear receptors during rat liver development. Am. J. Physiol. Gastrointest Liver Physiol. 2005, 288, G251-G260.

41. Kamiya, A.; Inoue, Y.; Gonzalez, F.J. Role of the hepatocyte nuclear factor 4alpha in control of the pregnane $\mathrm{X}$ receptor during fetal liver development. Hepatology 2003, 37, 1375-1384.

42. Klaassen, C.D.; Lu, H.; Cui, J.Y. Epigenetic regulation of drug processing genes. Toxicol. Mech. Methods 2011, 21, 312-324.

43. Jin, B.; Park, D.W.; Nam, K.W.; Oh, G.T.; Lee, Y.S.; Ryu, D.Y. CpG methylation of the mouse CYP1A2 promoter. Toxicol. Lett. 2004, 152, 11-18.

44. Lu, H.; Gunewardena, S.; Cui, J.Y.; Yoo, B.; Zhong, X.B.; Klaassen, C.D. RNA-sequencing quantification of hepatic ontogeny and tissue distribution of mRNAs of phase II enzymes in mice. Drug Metab. Dispos. 2013, 41, 844-857.

45. Alnouti, Y.; Klaassen, C.D. Tissue distribution and ontogeny of sulfotransferase enzymes in mice. Toxicol. Sci. 2006, 93, 242-255.

46. Richard, K.; Hume, R.; Kaptein, E.; Stanley, E.L.; Visser, T.J.; Coughtrie, M.W. Sulfation of thyroid hormone and dopamine during human development: Ontogeny of phenol sulfotransferases and arylsulfatase in liver, lung, and brain. J. Clin. Endocrinol. Metab. 2001, 86, 2734-2742.

47. Stanley, E.L.; Hume, R.; Coughtrie, M.W. Expression profiling of human fetal cytosolic sulfotransferases involved in steroid and thyroid hormone metabolism and in detoxification. Mol. Cell. Endocrinol. 2005, 240, 32-42.

48. Duanmu, Z.; Weckle, A.; Koukouritaki, S.B.; Hines, R.N.; Falany, J.L.; Falany, C.N.; Kocarek, T.A.; Runge-Morris, M. Developmental expression of aryl, estrogen, and hydroxysteroid sulfotransferases in pre- and postnatal human liver. J. Pharmacol. Exp. Ther. 2006, 316, 1310-1317.

49. Cappiello, M.; Giuliani, L.; Rane, A.; Pacifici, G.M. Dopamine sulphotransferase is better developed than P-nitrophenol sulphotransferase in the human fetus. Dev. Pharmacol. Ther. 1991, 16, 83-88.

50. Pacifici, G.M.; Kubrich, M.; Giuliani, L.; de Vries, M.; Rane, A. Sulphation and glucuronidation of ritodrine in human foetal and adult tissues. Eur. J. Clin. Pharmacol. 1993, 44, 259-264.

51. Miki, Y.; Nakata, T.; Suzuki, T.; Darnel, A.D.; Moriya, T.; Kaneko, C.; Hidaka, K.; Shiotsu, Y.; Kusaka, H.; Sasano, H. Systemic distribution of steroid sulfatase and estrogen sulfotransferase in human adult and fetal tissues. J. Clin. Endocrinol. Metab. 2002, 87, 5760-5768.

52. Parker, C.R., Jr.; Falany, C.N.; Stockard, C.R.; Stankovic, A.K.; Grizzle, W.E. Immunohistochemical localization of dehydroepiandrosterone sulfotransferase in human fetal tissues. J. Clin. Endocrinol. Metab. 1994, 78, 234-236.

53. Barker, E.V.; Hume, R.; Hallas, A.; Coughtrie, W.H. Dehydroepiandrosterone sulfotransferase in the developing human fetus: Quantitative biochemical and immunological characterization of the hepatic, renal, and adrenal enzymes. Endocrinology 1994, 134, 982-989.

54. Cui, J.Y.; Choudhuri, S.; Knight, T.R.; Klaassen, C.D. Genetic and epigenetic regulation and expression signatures of glutathione $S$-transferases in developing mouse liver. Toxicol. Sci. 2010, $116,32-43$.

55. Tee, L.B.; Gilmore, K.S.; Meyer, D.J.; Ketterer, B.; Vandenberghe, Y.; Yeoh, G.C. Expression of glutathione $S$-transferase during rat liver development. Biochem. J. 1992, 282, 209-218. 
56. Raijmakers, M.T.; Steegers, E.A.; Peters, W.H. Glutathione $S$-transferases and thiol concentrations in embryonic and early fetal tissues. Hum. Reprod. 2001, 16, 2445-2450.

57. Strange, R.C.; Davis, B.A.; Faulder, C.G.; Cotton, W.; Bain, A.D.; Hopkinson, D.A.; Hume, R. The human glutathione S-transferases: Developmental aspects of the GST1, GST2, and GST3 loci. Biochem Genet. 1985, 23, 1011-1028.

58. Kishi, M.; Emi, Y.; Sakaguchi, M.; Ikushiro, S.; Iyanagi, T. Ontogenic isoform switching of UDP-glucuronosyltransferase family 1 in rat liver. Biochem. Biophys. Res. Commun. 2008, 377, 815-819.

59. Burchell, B.; Coughtrie, M.; Jackson, M.; Harding, D.; Fournel-Gigleux, S.; Leakey, J.; Hume, R. Development of human liver UDP-glucuronosyltransferases. Dev. Pharmacol. Ther. 1989, 13, 70-77.

60. Rollins, D.E.; von Bahr, C.; Glaumann, H.; Moldeus, P.; Rane, A. Acetaminophen: Potentially toxic metabolite formed by human fetal and adult liver microsomes and isolated fetal liver cells. Science 1979, 205, 1414-1416.

61. Ekstrom, L.; Johansson, M.; Rane, A. Tissue distribution and relative gene expression of UDP-glucuronosyltransferases (2B7, 2B15, 2B17) in the human fetus. Drug Metab. Dispos. 2013, 41, 291-295.

62. Pacifici, G.M.; Sawe, J.; Kager, L.; Rane, A. Morphine glucuronidation in human fetal and adult liver. Eur. J. Clin. Pharmacol. 1982, 22, 553-558.

63. Leakey, J.E.; Hume, R.; Burchell, B. Development of multiple activities of UDP-glucuronyltransferase in human liver. Biochem. J. 1987, 243, 859-861.

64. McQueen, C.A.; Mitchell, M.K.; Dang, L.N.; Chau, B.; Tjalkens, R.B.; Philbert, M.A. Prenatal expression of $\mathrm{N}$-acetyltransferases in C57B1/6 mice. Chem. Biol. Interact. 2003, 145, 77-87.

65. Pacifici, G.M.; Bencini, C.; Rane, A. Acetyltransferase in humans: Development and tissue distribution. Pharmacology 1986, 32, 283-291.

66. Coughtrie, M.W. Sulfation through the looking glass-Recent advances in sulfotransferase research for the curious. Pharmacogenomics J. 2002, 2, 297-308.

67. Her, C.; Kaur, G.P.; Athwal, R.S.; Weinshilboum, R.M. Human sulfotransferase SULT1C1: cDNA cloning, tissue-specific expression, and chromosomal localization. Genomics 1997, 41, 467-470.

68. Hobkirk, R. Steroid sulfotransferases and steroid sulfate sulfatases: Characteristics and biological roles. Can. J. Biochem Cell. Biol. 1985, 63, 1127-1144.

69. Knight, T.R.; Choudhuri, S.; Klaassen, C.D. Constitutive mRNA expression of various glutathione $S$-transferase isoforms in different tissues of mice. Toxicol. Sci. 2007, 100, 513-524.

70. Thomson, R.E.; Bigley, A.L.; Foster, J.R.; Jowsey, I.R.; Elcombe, C.R.; Orton, T.C.; Hayes, J.D. Tissue-specific expression and subcellular distribution of murine glutathione $S$-transferase class kappa. J. Histochem. Cytochem. 2004, 52, 653-662.

71. Li, W.; Gu, Y.; James, M.O.; Hines, R.N.; Simpson, P.; Langaee, T.; Stacpoole, P.W. Prenatal and postnatal expression of glutathione transferase zeta 1 in human liver and the roles of haplotype and subject age in determining activity with dichloroacetate. Drug Metab. Dispos. 2012, 40, 232-239.

72. Evans, W.E.; Relling, M.V. Pharmacogenomics: Translating functional genomics into rational therapeutics. Science 1999, 286, 487-491. 
73. Mitchell, M.K.; Futscher, B.W.; McQueen, C.A. Developmental expression of $N$-acetyltransferases in C57BI/6 mice. Drug Metab. Dispos. 1999, 27, 261-264.

74. Araki, Y.; Sakakibara, Y.; Boggaram, V.; Katafuchi, J.; Suiko, M.; Nakajima, H.; Liu, M.C. Tissue-specific and developmental stage-dependent expression of a novel rat Dopa/tyrosine sulfotransferase. Int. J. Biochem. Cell. Biol. 1997, 29, 801-806.

75. Liu, L.; Klaassen, C.D. Ontogeny and hormonal basis of female-dominant rat hepatic sulfotransferases. J. Pharmacol. Exp. Ther. 1996, 279, 386-391.

76. Liu, L.; Klaassen, C.D. Ontogeny and hormonal basis of male-dominant rat hepatic sulfotransferases. Mol. Pharmacol. 1996, 50, 565-572.

77. Sonoda, J.; Xie, W.; Rosenfeld, J.M.; Barwick, J.L.; Guzelian, P.S.; Evans, R.M. Regulation of a xenobiotic sulfonation cascade by nuclear pregnane X receptor (Pxr). Proc. Natl. Acad. Sci. USA 2002, 99, 13801-13806.

78. Fang, H.L.; Strom, S.C.; Cai, H.; Falany, C.N.; Kocarek, T.A.; Runge-Morris, M. Regulation of human hepatic hydroxysteroid sulfotransferase gene expression by the peroxisome proliferator-activated receptor alpha transcription factor. Mol. Pharmacol. 2005, 67, 1257-1267.

79. Hempel, N.; Wang, H.; LeCluyse, E.L.; McManus, M.E.; Negishi, M. The human sulfotransferase SULT1A1 gene is regulated in a synergistic manner by $\mathrm{Sp} 1$ and GA binding protein. Mol. Pharmacol. 2004, 66, 1690-1701.

80. Cui, J.Y.; Gunewardena, S.S.; Yoo, B.; Liu, J.; Renaud, H.J.; Lu, H.; Zhong, X.B.; Klaassen, C.D. RNA-Seq reveals different mRNA abundance of transporters and their alternative transcript isoforms during liver development. Toxicol. Sci. 2012, 127, 592-608.

81. Gao, B.; St Pierre, M.V.; Stieger, B.; Meier, P.J. Differential expression of bile salt and organic anion transporters in developing rat liver. J. Hepatol. 2004, 41, 201-208.

82. Chen, H.L.; Liu, Y.J.; Feng, C.H.; Wu, C.Y.; Shyu, M.K.; Yuan, R.H.; Chang, M.H. Developmental expression of canalicular transporter genes in human liver. J. Hepatol. 2005, 43, 472-477.

83. Sharma, S.; Ellis, E.C.; Gramignoli, R.; Dorko, K.; Tahan, V.; Hansel, M.; Mattison, D.R.; Caritis, S.N.; Hines, R.N.; Venkataramanan, R.; et al. Hepatobiliary disposition of 17-OHPC and taurocholate in fetal human hepatocytes: A comparison with adult human hepatocytes. Drug Metab. Dispos. 2013, 41, 296-304.

84. Hardikar, W.; Ananthanarayanan, M.; Suchy, F.J. Differential ontogenic regulation of basolateral and canalicular bile acid transport proteins in rat liver. J. Biol. Chem. 1995, 270, 20841-20846.

85. St-Pierre, M.V.; Stallmach, T.; Freimoser Grundschober, A.; Dufour, J.F.; Serrano, M.A.; Marin, J.J.; Sugiyama, Y.; Meier, P.J. Temporal expression profiles of organic anion transport proteins in placenta and fetal liver of the rat. Am. J. Physiol. Regul. Integr. Comp. Physiol. 2004, 287, R1505-R1516.

86. Alnouti, Y.; Petrick, J.S.; Klaassen, C.D. Tissue distribution and ontogeny of organic cation transporters in mice. Drug Metab. Dispos. 2006, 34, 477-482.

87. Cheng, X.; Maher, J.; Chen, C.; Klaassen, C.D. Tissue distribution and ontogeny of mouse organic anion transporting polypeptides (Oatps). Drug Metab. Dispos. 2005, 33, 1062-1073.

88. Van Kalken, C.K.; Giaccone, G.; van der Valk, P.; Kuiper, C.M.; Hadisaputro, M.M.; Bosma, S.A.; Scheper, R.J.; Meijer, C.J.; Pinedo, H.M. Multidrug resistance gene (P-glycoprotein) expression in the human fetus. Am. J. Pathol 1992, 141, 1063-1072. 
89. Rosati, A.; Maniori, S.; Decorti, G.; Candussio, L.; Giraldi, T.; Bartoli, F. Physiological regulation of P-glycoprotein, MRP1, MRP2 and cytochrome P450 3A2 during rat ontogeny. Dev. Growth Differ. 2003, 45, 377-387.

90. Cui, Y.J.; Cheng, X.; Weaver, Y.M.; Klaassen, C.D. Tissue distribution, gender-divergent expression, ontogeny, and chemical induction of multidrug resistance transporter genes (Mdr1a, Mdr1b, Mdr2) in mice. Drug Metab. Dispos. 2009, 37, 203-210.

91. Zinchuk, V.S.; Okada, T.; Akimaru, K.; Seguchi, H. Asynchronous expression and colocalization of Bsep and Mrp2 during development of rat liver. Am. J. Physiol. Gastrointest Liver Physiol. 2002, 282, G540-G548.

92. Maher, J.M.; Slitt, A.L.; Cherrington, N.J.; Cheng, X.; Klaassen, C.D. Tissue distribution and hepatic and renal ontogeny of the multidrug resistance-associated protein (Mrp) family in mice. Drug Metab. Dispos. 2005, 33, 947-955.

93. Dubuisson, C.; Cresteil, D.; Desrochers, M.; Decimo, D.; Hadchouel, M.; Jacquemin, E. Ontogenic expression of the $\mathrm{Na}(+)$-independent organic anion transporting polypeptide (oatp) in rat liver and kidney. J. Hepatol. 1996, 25, 932-940.

94. Lee, J.S.; Ward, W.O.; Liu, J.; Ren, H.; Vallanat, B.; Delker, D.; Corton, J.C. Hepatic xenobiotic metabolizing enzyme and transporter gene expression through the life stages of the mouse. PLoS One 2011, 6, e24381.

95. Fakhoury, M.; de Beaumais, T.; Guimiot, F.; Azougagh, S.; Elie, V.; Medard, Y.; Delezoide, A.L.; Jacqz-Aigrain, E. mRNA expression of MDR1 and major metabolising enzymes in human fetal tissues. Drug Metab. Pharmacokinet 2009, 24, 529-536.

96. Klaassen, C.D.; Aleksunes, L.M. Xenobiotic, bile acid, and cholesterol transporters: Function and regulation. Pharmacol. Rev. 2010, 62, 1-96.

97. Tomer, G.; Ananthanarayanan, M.; Weymann, A.; Balasubramanian, N.; Suchy, F.J. Differential developmental regulation of rat liver canalicular membrane transporters Bsep and Mrp2. Pediatr. Res. 2003, 53, 288-294.

98. Zhou, S.; Zong, Y.; Ney, P.A.; Nair, G.; Stewart, C.F.; Sorrentino, B.P. Increased expression of the Abcg2 transporter during erythroid maturation plays a role in decreasing cellular protoporphyrin IX levels. Blood 2005, 105, 2571-2576.

99. Boyer, J.L.; Hagenbuch, B.; Ananthanarayanan, M.; Suchy, F.; Stieger, B.; Meier, P.J. Phylogenic and ontogenic expression of hepatocellular bile acid transport. Proc. Natl. Acad. Sci. USA 1993, 90, 435-438.

100. Suchy, F.J.; Bucuvalas, J.C.; Goodrich, A.L.; Moyer, M.S.; Blitzer, B.L. Taurocholate transport and $\mathrm{Na}^{+}-\mathrm{K}^{+}$-ATPase activity in fetal and neonatal rat liver plasma membrane vesicles. Am. J. Physiol. 1986, 251, G665-G673.

101. Landry, C.; Clotman, F.; Hioki, T.; Oda, H.; Picard, J.J.; Lemaigre, F.P.; Rousseau, G.G. HNF-6 is expressed in endoderm derivatives and nervous system of the mouse embryo and participates to the cross-regulatory network of liver-enriched transcription factors. Dev. Biol. 1997, 192, 247-257.

(C) 2013 by the authors; licensee MDPI, Basel, Switzerland. This article is an open access article distributed under the terms and conditions of the Creative Commons Attribution license (http://creativecommons.org/licenses/by/3.0/). 